\title{
Labor Intensity and Expected Stock Returns
}

\author{
Gilles Chemla \\ Peter Pontuch*
}

February 15, 2012

\begin{abstract}
This paper analyses the effects of labor intensity on a firm's operating risk and its expected stock returns. We isolate a pure labor intensity effect by using a relative measure with respect to the three-digit industry median level. We show that labor intensity is positively associated with operating leverage, at least in the small and medium-sized firms subsample. Stock and portfolio returns of small and, to a lesser extent, midcap firms are positively associated with labor intensity after controlling for traditional risk factors. In particular, the labor-induced operating leverage does not seem to be explained by the book-to-market factor. The relationship between labor intensity and stock returns is stronger in low wage industries and at medium levels of financial leverage.
\end{abstract}

Keywords: labor intensity, operating leverage, expected stock returns, cross-section of stock returns.

JEL Classifications: G31, D24, G12.

${ }^{*}$ Chemla: Imperial College Business School, DRM/CNRS and CEPR. Pontuch: Université Paris Dauphine DRM Finance. We thank Christina Atanasova, Laurent Calvet, Denis Gromb, Gaëlle Le Fol, Oguzhan Karakas, Gordon Phillips, and seminar participants at the Universty of Maryland, College Park, in particular Michael Faulkender and Gerard Hoberg, and Université Paris-Dauphine. All errors are our own. Pontuch gratefully acknowledges financial support from the FBF Chair in Corporate Finance, as well as kind hospitality of the Department of Finance at the University of Maryland, College Park. 


\section{Introduction}

Firms face a significant level of discretion in deciding how to organize their production process. For a given set of technological constraints a firm can achieve a certain level of production using different proportions of inputs (e.g. labor, capital, basic resources, intermediate goods). These choices affect the firm's structure of costs and claims, and thus have likely implications for the riskiness of its cash flows. The level of labor intensity is a prominent example of such a choice. Labor expenses are known to be relatively stable over time and are senior to investors' claims. They affect mechanically the variability of residual cash flows and should therefore be reflected in firm valuations.

The financial effects of labor have recently been studied with respect to their quasi-fixed nature (e.g. Danthine and Donaldson (2002), Merz and Yashiv (2007)), the inflexibility due to unionization (Chen, Kacperczyk, and Ortiz-Molina (2011)), and the implications of labor mobility (Donangelo (2011)). In all of these studies labor exposure generates some kind of operating inflexibility and thereby increases a firm's risk.

It is empirically challenging, however, to attribute observed regularities to a pure labor effect. In fact, the inter-industry variability in labor intensity is high (see Donangelo (2011)). Portfolio sorts based on labor intensity are likely to concentrate firms from capital intensive industries (say Primary Metal Industries) at one end, and from labor intensive industries (like Business Services) at the other end. The sensitivity of these industries to aggregate factors is likely to be very different. Any observed effect in such sorted portfolios may not necessarily be solely related to the labor exposure per se.

The objective of this paper is to isolate a pure effect of labor intensity on the riskiness of firms' operations and on their stock returns. We propose to measure labor intensity relative to an industry "normal" (the SIC3 median). We define two relative labor intensity (RLI) measures using assets per employee and operating assets per employee. Sorting based on a relative measure of labor intensity gives all industries almost equal chances of being represented at both ends of the distribution of labor intensity. Our approach is similar in spirit to an industry-matched estimation of the effect of labor intensity. 
There are at least three possible reasons why labor intensity could affect firm risk. First, in presence of high labor adjustment costs the labor expenses are quasi-fixed and produce an operating leverage effect. Second, if labor productivity volatility is much higher than the volatility of unit wages, then labor exposure creates also an operating risk. Note that this is true even if adjustment costs are moderate. Third, labor intensive firms simply face a higher human capital turnover risk. They are relatively more vulnerable to losses of human capital due to layoffs.

We show that relative labor intensity is positively related to operating leverage, at least in small and medium-sized firms. This higher operating leverage is reflected in individual stock returns. Small and mid-sized firms have a positive association between returns and labor intensity, even if we control for other traditional firm-level determinants of returns. A similar conclusion is present in sorted portfolios' average returns: a strong effect of RLI in small firms portfolios, and an effect of RLI on equally weighted returns of mid-cap portfolios.

Time series regressions of double sorted portfolios confirm previous results, but also reveal an interesting link between mappings on the B/M factor (HML) and abnormal returns of RLI-sorted portfolios. We find positive abnormal returns on Large firms with low RLI, and they appear accompanied with a particularly strong negative mapping on the HML factor. We show that these abnormal returns on Large firms occurred during the late 1990s' period of the high-tech boom.

In previous literature the $\mathrm{B} / \mathrm{M}$ factor was suggested to capture the effects of operating leverage (see e.g. Carlson, Fisher, and Giammarino (2004)). One of the main messages of our paper is that the $\mathrm{B} / \mathrm{M}$ factor does pick up a part of the risks induced by labor intensity, but some abnormal returns patterns survive even in a 4 -factor setting.

To judge the three alternative mechanisms through which labor intensity affects firm risk, we split our sample based on the level of industry wages. The latter is a proxy for both the importance of human capital and the level of adjustment costs. Our findings do not seem to be consistent with either an adjustment costs story, or a human capital turnover story. Though statistically weak, our results seem only consistent with a mechanism based on the 
wedge between volatile productivity and sticky wages.

Lastly, we show that financial leverage affects the relationship between labor intensity and expected stock returns. We show that stock returns are at least moderately increasing in labor intensity for firms having a medium-level of debt.

The paper is organized as follows. We first present related literature and then formulate our hypotheses in section 2. We construct our proxies for labor intensity in section 3 . We analyze the effects of labor intensity on operating leverage in section 5. We study individual stock returns in section 6.2. Average portfolio returns are analyzed in section 6.3, while time-series regressions of portfolio returns are presented in section 6.4.

\section{Background and problem formulation}

Research on operating leverage and returns goes back at least to Lev (1974) who shows in a simple analytical framework that operating leverage increases the systematic risk of a company's stock. Mankelder and Rhee (1984) formalize the relationship between a stock's systematic risk and the operating and financial leverage of the company's fundamentals. The authors find that these two components explain a large part of companies' beta and they find support for the hypothesis of a trade-off between the two sources.

In a more recent study Penman, Richardson and Tuna (2007) decompose the B/M ratio into a B/M component of assets (capturing operating leverage) and a financial leverage component. The authors find that conditionally on the asset $\mathrm{B} / \mathrm{M}$ ratio, financial leverage earns a surprising negative premium. Gomes and Schmid (2009) use the idea of changing firm risk over the firm's life cycle to explain these empirical puzzles of financial leverage and stock returns. Their investment-based asset pricing model explicitly takes into account the endogeneity of financing and investment decisions. Specifically, highly levered firms tend to be large and with lower underlying asset risk. On the other hand, small firms are, within their general model, more subject to operating leverage and they face (relatively) higher fixed costs of bankruptcy (p.487).

Operating leverage plays an important role in the real options literature. In particular, Carlson, Fisher and Giammarino (2004) model firms holding a finite number of growth options 
on projects with constant asset risk. The exercise of options materializes in increased operating leverage. If the fixed costs are proportional to the capital level, a B/M effect arises from the interaction of these fixed cost commitments and the variability of the aggregate demand conditions.

The role of labor induced operating leverage is the focus of Danthine and Donaldson (2002). They motivate their model by the observation that the aggregate labor share is highly variable over the business cycle, suggesting that risk transfers occur between providers of labor and capital. The seniority of labor expenses generates operating risk for equity holders which, if it remains uninsurable, increases the risk premium on equity claims. This result is obtained at the aggregate level by separating agents into workers with no participation in financial markets and investors with no labor income.

Merz and Yashiv (2007) adapt the adjustment cost framework from the corporate investment literature and apply it to both investment and hiring decisions. They show that in this setting firm value is determined by both the capital stock and the total employment of a company. This result obtains due to a positive shadow price of employment in this setting generated by adjustment costs. There is no link between the riskiness of earnings and the level of employment in this model. Bazdresch, Belo and Lin (2008) extend this reasoning and provide empirical and theoretical evidence that both investment and hiring decisions help explain the cross section of returns. In particular, their forward-looking nature makes them a good proxy for the conditional beta of the firm (idea already formulated by Merz and Yashiv, 2007).

Our paper is closely related to Gourio (2007). He starts with the stylized fact that wages do not fully adjust to changes in labor productivity due to rigidities. Labor intensive firms have a long position in the volatile labor productivity and a short position in less volatile wages. This mechanism is akin to operating leverage and results in higher pro-cyclicality of earnings. The higher the labor share of a company (or, equivalently, the lower the capital share) the more pro-cyclical are the earnings. In his own words "firms which have high labor costs 'leverage' the smoothness of wages" Gourio (2007, p. 8). Given a production technology a firm with a higher idiosyncratic factor productivity will have a higher capital share if and only if the elasticity 
of substitution is less than unity. In the empirical application he shows that the sensitivity of corporate earnings is increasing in labor leverage, i.e. systematic risk is also increasing. This finding is used to develop a two-factor asset pricing model based on aggregate real wage and total factor productivity. High $\mathrm{B} / \mathrm{M}$ firms have higher betas on the productivity factor and lower beta on the wage factor.

Donangelo (2011) develops a similar idea based on workers' interindustry mobility. He argues that highly mobile workers prevent firms from adjusting wages downwards following adverse industry-specific shocks. This increases earnings' exposure to these shocks and generates an operating leverage effect. He develops an industry measure of labor mobility and shows that it is positively associated with operating leverage and expected stock returns. One caveat regarding the empirical results is that the measure of labor mobility seems to pick up mostly manufacturing industries as highly mobile. The observed returns differentials could therefore be related to a sectoral story instead.

The objective of this study is to isolate a pure effect of labor intensity. In particular, we wish to study an effect that is orthogonal to industry effects (cyclicality of demand, competitive mechanisms, technology life-cycle). Our empirical approach is therefore to measure labor intensity of firms relative to their industry normal level. By construction, each industry contributes to both the high and the low end of the distribution of the relative measure of labor intensity. We address two research questions. Does relative labor intensity affect companies' operating leverage? If yes, is this additional risk captured by traditional risk factors or does it generate abnormal returns?

Based on the previous discussion of the literature we formulate two research hypotheses:

H1: Labor intensive firms have a higher level of fundamental risk. There are at least three possible mechanisms through which labor intensity could affect firm risk.

First, if there are significant adjustment costs on labor (as in Merz and Yashiv (2007), Bazdresch et al. (2008)), labor adjustments are lumpy and firms will commonly operate above or below optimum levels. In this case labor expense is a quasi-fixed cost and generates operating leverage. 
Second, if there is a wedge between a sticky wage and a volatile productivity, then labor intensive firms will have more leveraged earnings (Gourio (2007), Donangelo (2011)). Note that this mechanism will hold even if adjustment costs are low, since the argument is formulated in terms of wage and productivity per unit of labor. In downturns, output per unit of labor decreases more than the per unit cost of labor dragging down operating margins. This effect will be stronger in labor intensive firms.

Third, labor intensive firms face a higher labor turnover risk. Investments in human capital are completely lost in downsizing, as opposed to a partial recovery of costs in the case of disposal of physical capital. Labor intensive firms could be less willing to reduce scale in downturns, at least in human capital intensive industries. Again, this would lead to a higher level of operating leverage.

H2 - Due to riskier fundamentals, labor intensive firms earn higher average returns. Operating leverage amplifies the variability of earnings following shocks to sales. These shocks can either reflect the state of the economy, or be firm-specific. At least a part of the additional risk borne by labor intensive firms is systematic and should be reflected in higher betas. In particular, if the B/M factor (HML) captures the effects of operating leverage, then it should pick up the additional systematic risk of labor intensive firms.

\section{Measuring labor intensity}

The ideal measure of labor intensity would be derived from the Compustat item Staff expense (field 42, "xlr"). scaled by some measure of the size of operations like sales. However, the expense field is only available for less than $10 \%$ of firm-years in the Compustat database.

We therefore use another labor-related item, one that is provided almost systematically, Number of employees (field 29, "emp"). We take into account differences in size by taking the workforce size relative to a reference asset group. Throughout the paper we will actually use the inverse, i.e. assets per employee variables. We use two reference asset groups to construct two raw measures of labor intensity: 
- APE - total assets per employee,

- OAPE - operating assets (assets minus cash \& S-T instruments) per employee.

There are at least two problems with using such raw measures of labor intensity. First, labor is not a homogeneous factor across industries and different industries require a different blend of skilled vs. non-skilled labor (see Bazdresch et al., 2008). Therefore 100 employees in the mining industry are not directly comparable to the same number of employees in the medical instruments industry.

Second, production technologies are very different across industries (and arguably even across firms), so different industries may require very different levels of labor intensity at the optimum. Sorting based on these raw measures would lead to portfolios concentrated in specific industries. Results observed across such sorted portfolios could as well be driven by some other latent variable and not directly related to labor intensity per se.

Our answer to these issues is to use a measure of relative labor intensity. We define relative labor intensity as the raw measure of labor intensity of firm $i$ divided by the median of its 3-digit SIC industry, minus one. For example, relative labor intensity measured by assets per employee is defined for firm $i$ at date $t$ as

$$
\mathrm{APE}_{i t}^{\mathrm{rel}}=\frac{\mathrm{APE}_{i t}}{\mathrm{APE}_{i t}^{\mathrm{SIC}}}-1
$$

Defined in this fashion, our measure of relative labor is bounded below by -1 . This measure is similar in spirit to the technological natural hedge by MacKay and Phillips (2005). Without further precision the acronyms APE and OAPE will hereinafter refer to these relative measures of labor intensity.

\section{Data}

We use data on U.S. incorporated public companies from the Compustat CRSP merged database. We exclude financial companies (SIC codes between 6000 and 6999) and utilities (SIC 4900 to 4999). We require valid (and positive, where applicable) values for total assets, 
total liabilities, property, plant\&equipment, debt, cash, employees, shares outstanding, share price, sales, net income, operating income, depreciation, costs of goods sold, common and preferred dividends. We exclude firm-years with book assets below $\$ 10$ million or with common equity below $\$ 5$ million, both in constant 1994 dollars.

Book equity is total assets minus total liabilities minus preferred stock (standard FamaFrench order in the definition of preferred stock) plus balance sheet deferred taxes and investment tax credits. $\mathrm{B} / \mathrm{M}$ of equity is defined as book equity divided by share price times shares outstanding. We winsorize ratio variables at the $1 \%$ level to minimize the influence of extreme variables in regressions. When sorting portfolios on measures of relative labor leverage we use labor exposure data from fiscal year t-1. Our sample period on annual financial data is 1975-2009.

We present summary statistics in table 1 . Sample firms have a median size of approx. 170 million 1994 dollars and 1,300 employees. Median ROA is about 6.7\%, median B/M of assets 1.3 and median real sales growth $5.8 \%$. Firms invest about $4.8 \%$ of their assets. We present in panels B through D some descriptive statistics for the 1st, 3rd and 5th quintile groups sorted on a proxy of relative labor intensity (inversely sorted on assets per employee minus SIC3 median). The most labor intensive firms are smaller and slightly more profitable. They also have a lower and less volatile sales growth and a higher investment rate.

Our monthly returns data from CRSP cover the period July 1976 to December 2009 (we need a first year of fundamentals data in order to sort portfolios). When merging returns data with Compustat variables we only keep primary joiner issues. We perform portfolio sorts at the end of June of each year $t$. We use B/M equity ratios as of December of year $\mathrm{t}-1$, market capitalization data as of June of year $t$, and accounting data as well as relative labor exposures from fiscal year t-1 ensuring that all sorts are performed using available data as of the sort date. The monthly factor returns as well as the risk-free rate come from Kenneth French's web page.

We adjust average returns following the methodology by Daniel, Grinblatt, Titman, and Wermers (1997) and Wermers (2004) and use Russ Wermers's benchmark data. ${ }^{1}$

\footnotetext{
${ }^{1}$ http://www. smith. umd.edu/faculty/rwermers/ftpsite/Dgtw/coverpage.htm.
} 


\section{$5 \quad$ Labor intensity and operating leverage}

In this part we establish the effect of labor intensity on the operating leverage of firms. To this end we independently sort firms into $3 \times 5$ groups each year using previous year's size $(3$ groups) and relative labor intensity (5 groups). The size groups are defined using the 20th and 50th NYSE capitalization percentiles. Relative labor intensity groups are defined based on previous year's distribution quintiles.

The degree of operating leverage is originally defined as the percentage change of operating earnings in response to a one percent change in units sold. In general firms sell more than one type of product and therefore a feasible specification is to use sales instead of units sold (see for example Lev (1974)). The basic specification that we estimate is:

$$
\Delta \ln \left(\mathrm{OI}_{i t}\right)=\alpha_{k}+\beta_{k} \Delta \ln \left(\operatorname{Sales}_{i t}\right)+\epsilon_{i t}
$$

We run a separate estimation for each group $k$ (one of the 15 size-RLI groups) on all firms $i \in k$ in year $t$. To deal with the problem of corporate events (mergers, spinoffs, large asset disposals) that could seriously bias the year-over-year growth rates of either sales or OI, we exclude firm-years which have an asset growth above $+100 \%$ or below $-50 \%$.

We estimate the equation using a firm-wise Fama-MacBeth procedure following Skoulakis (2008). We start by time-demeaning the data for each size-RLI group. Then for each firm in a given group we run a time-series regression. We require at least 5 observations per firm within that given group. We then average the coefficient estimates over the firms within the group to obtain point estimates. We estimate the coefficient SEs based on the dispersion of firm estimates.

We present in table 2 the results of our estimation. In panel A we use assets per employee as measure of RLI. In small firms, the difference between the most and the least labor intensive groups is about 0.6 points. Operating leverage increases slightly from $\mathrm{H}$ to RLI3 but the difference remains low. The R-squared indicates that there is more residual variability in the most leveraged group. Small firms with a high RLI have therefore both a higher operating 
leverage and more volatile earnings. In medium-sized firms, the relationship is not completely monotonic. Operating leverage is clearly decreasing from RLI4 to L. The H group, however, has only a slightly higher coefficient than the L group. In large firms there is no apparent relationship between operating leverage and RLI. The mid-RLI group is the most operating leveraged one. Lastly, the R-squareds are in general higher in the big size groups, suggesting that residual volatility is lowest in big firms.

In panel B the results using operating assets per employee are broadly similar. In small firms the $\mathrm{H}-\mathrm{L}$ difference, at 0.37 points, is smaller than in panel A but still economically significant. The coefficients in RLI4 and RLI3 are higher than in the previous case. There is however a clear positive difference between the left and the right end of the small firms coefficients. In medium-sized firms, the pattern is less clear cut than in panel A. The decreasing patter is broadly preserved in the RLI4 to L groups, but the H coefficient is clearly the lowest. Again, a non-monotonic pattern appears with the RLI3 group having the highest coefficient.

The analysis in this part yielded partial evidence in favor of our H1 hypothesis. Operating leverage is increasing in relative labor intensity in small firms. There was some evidence of a similar effect in medium-sized firms. Large firms do not show any similar relationship.

\section{$6 \quad$ Expected stock returns}

\subsection{Sorting methodology}

We now turn to stock returns data to inspect whether the risk patterns that we documented in the previous section have any implications in terms of stock returns. In section 6.2 dealing with individual stock returns we use the levels of the RLI proxies along with other variables documented to be firm-level determinants of stock returns (size, B/M, momentum).

In sections 6.3 and 6.4 we construct portfolio sorts based on the two measures of relative labor intensity, APE and OAPE. We also perform independent double sorts based on size and RLI measures. Our sorting methodology respects the standard approach (see for instance Fama and French (2008)). Specifically, we independently sort portfolios at the end of June of 
year $t$ by market capitalization and by a proxy for relative labor intensity (RLI). We use the quintiles of the RLI distribution that excludes small firms (to avoid their over-influence due to their high number). We keep this portfolio structure constant when calculating July $t$ to June $t+1$ returns. We define three size groups based on the 20th and 50th NYSE market capitalization percentiles in June t. We sort firms into five groups based on the year $t-1$ RLI distribution quintiles. The H portfolio (L portfolio) is the $20 \%$ of observations with the highest (lowest) RLI i.e. the least (most) assets per employee as of June $t$.

\subsection{Individual stock returns}

In table 3 we run regressions of individual stock returns on firm-level determinants. We use the time-wise Fama-MacBeth methodology, as this time we have a larger number of dates (402 monthly observations). Every month we run a cross-sectional regression of returns on a set of firm-level determinants. We then take the average of the estimated coefficients over all months. We estimate the standard error with a Newey-West 4 lags correction and provide a t-statistic for coefficients. We also report average R-squared from the cross-sectional regressions.

Panel A, based on the relative APE measure, confirms that there is a significant positive association between labor intensity and expected stock returns. In the standalone specification, the coefficient is significant (about 4 standard deviations from zero) but the explained variability is very low (R-squared of $0.1 \%$ ). When used alongside Size, the APE coefficient remains significant while size's coefficient is below the $10 \%$ significance threshold. Interestingly, the R-squared improves more than ten times. The APE significance survives when used alongside the $\mathrm{B} / \mathrm{M}$ and the previous return momentum variables. Lastly, when all variables are used altogether, the APE coefficient remains about 3.6 standard deviations from zero, while the size coefficient is further reduced and not significant.

Panel B provides an identical picture. In all specifications the relative OAPE variable retains a significant coefficient, at least 3.7 standard deviations from zero. Size is again close to but below the $10 \%$ significance level in the specification with APE, but loses its significance completely in the all variables specification. 
Our results suggest that a firm that has a labor intensity $100 \%$ below its industry median (i.e. its APE is double the industry APE) earns on average a lower return by about $1 \%$ per year. The low R-squared obtained by the APE/OAPE variables is worth being discussed. On the one hand, it is not surprising given that we regress monthly returns of individual stocks on a firm characteristic that is relatively stable over time and changes only once a year. On the other hand, it adds a caveat to our results. At a minimum, in order to benefit from the return differential through a long-short position an investor has to construct a very well diversified portfolio that reduces the variability of individual stock returns.

Given the results from section 5 we further inspect whether these abnormal returns in individual stock returns persist in all size groups (our approach is similar to Fama and French (2008)). Table 4 presents results using the APE proxy. In the small firms subsample $(<20$ th NYSE percentile) the coefficient of the labor intensity proxy is negative and significant, about 4 standard deviations below zero. The medium-sized subsample (between the 20th and 50th NYSE percentiles) shows a lower coefficient in absolute terms that is still significant (about 1.7 standard deviations below zero). The large subsample (>50th NYSE percentile) also has a negative coefficient but it is clearly not significant (0.72 standard deviations below zero).

In summary, individual stock returns show a statistically significant effect of the two labor intensity proxies but the variability explained by this variable is very small. The effect is mostly due to small and medium-sized firms. The coefficient in the large cap subsample does have the same negative sign, but is not significant.

\subsection{Average returns of sorted portfolios}

We now use our sorting procedure detailed in section 6.1 to analyze average returns of size/RLI sorted portfolios. Our results for the two RLI proxies are presented in tables 5 (APE) and 6 (OAPE). In a first step we calculate value weighted and equally weighted average returns for each month in our sample period from July 1976 to December 2009. We then calculate simple averages over all 402 months. We calculate excess returns against the risk-free rate (Kenneth French data) and adjusted returns with respect to their DGTW benchmarks based 
on size, B/M and momentum (following Daniel et al. (1997), and Wermers (2004), using Russ Wermers's data).

Table 5 again suggests that there is some relationship between labor intensity (APE proxy) and average returns. In Panel A using all firms we observe that equally-weighted average excess returns are decreasing in APE, while value-weighted returns are somewhat decreasing as well. The difference $\mathrm{H}-\mathrm{L}$ is about $34 \mathrm{bp}$ for $\mathrm{E}-\mathrm{W}$ returns and about 9 bp for $\mathrm{V}-\mathrm{W}$ excess returns, but only the former is significant. In adjusted returns the difference is $25 \mathrm{bp}$ for E-W returns and less than 5 bp for V-W returns. Again only the E-W difference is significant.

We also note in panel $\mathrm{A}$ that the average size of firms is increasing as we move from $\mathrm{H}$ to L labor intensity portfolio. Therefore we provide average returns per size category in panels B through D. After sorting by size, average ME indicates that we have effectively controlled for almost all the variability in average size within Small and Medium companies. There is however some residual variability in Large companies, suggesting that the largest companies tend to concentrate towards the Low end of labor intensity.

In panel B we observe that average excess returns and adjusted returns are strongly decreasing in labor intensity for both $\mathrm{V}-\mathrm{W}$ and $\mathrm{E}-\mathrm{W}$ portfolios. The $\mathrm{H}-\mathrm{L}$ return differential is in all cases in the range $30-35$ bp per month (3.6\% to $4.3 \%$ annual), significant in all four instances. In panel C, mid-sized companies' excess returns and adjusted returns are decreasing only in the E-W case. The H-L differential is 14 and 12.5 bp per month respectively (about $1.7 \%$ and $1.5 \%$ annual). In panel $\mathrm{D}$, the $\mathrm{H}-\mathrm{L}$ adjusted returns differential is $3.5 \mathrm{bp} / \mathrm{month}$ both (EW and VW), i.e. positive but statistically and economically not significant.

Results using the OAPE proxy in table 6 confirm these patterns. Without size sorting (Panel A) the relationship between RLI and average returns is present, positive and significant in E-W portfolios. The equally weighted DGTW-adjusted $\mathrm{H}-\mathrm{L}$ return differential is about 30 $\mathrm{bp} /$ month (3.6\% annual).

In small firms (Panel B) excess returns and adjusted returns are increasing in RLI. The $\mathrm{H}-\mathrm{L}$ differentials are even stronger than in the APE case: e.g. for adjusted returns the differential is $33 \mathrm{bp}(\mathrm{V}-\mathrm{W})$ and $36 \mathrm{bp}(\mathrm{E}-\mathrm{W})$ per month. In medium-sized firms only the E-W 
differentials are significant (about 18bp both excess and adjusted returns). In large firms the $\mathrm{H}-\mathrm{L}$ differences are small and not significant.

To sum up, the portfolio average returns confirm previous finidings. RLI does have a positive association with expected stock returns, but only in small firms and, to a lesser extent, in medium-sized firms. In large firms, the average return differentials between high and low labor intensity portfolios are positive but not significant (statistically or economically).

\subsection{Time series asset pricing tests}

\subsubsection{Long-term analysis}

In this section we will continue our analysis on sorted portfolios by running time series asset pricing tests. We will use a standard 4-factor Fama-French-Carhart asset pricing model based on factor data from Kenneth French's webpage. For each double sorted portfolio we regress the $\mathrm{V}-\mathrm{W}$ and E-W excess returns on the market excess return, the SMB factor, the HML factor and the MOM factor. We then analyze the significance of the intercept from these regressions using Newey-West adjusted SEs (4 lags).

Table 7 presents the estimated coefficients from these regressions. We see on the left panel (E-W returns) that in the Small subsample the intercept is positive and statistically significant (61 bp) at the high end of RLI and that it decreases with RLI down to the L portfolio where it is not significant and lower in magnitude (24 bp). In the Medium subsample the high end of RLI earns a significant alpha of about $17 \mathrm{bp}$ and it decreases down to a not significant 1 bp for the L portfolio. Large E-W portfolios have also some significant alphas but with no discernible monotonic pattern.

There seems to be an interesting link between the significance of the alphas and the significance of the HML coefficient. In effect, for small and medium-sized firms the coefficients' significance either appears for both, or for neither. Also, for all size groups the High RLI end seems to map more positively on the HML factor, consistent with the idea that $\mathrm{B} / \mathrm{M}$ is a control for operating leverage (see Carlson et al. (2004)).

As we move to the $\mathrm{V}$-W portfolios in the right panel, we need to keep in mind that significant 
intercepts will become more rare (see discussion by Fama and French (2008)). We see a clear decreasing pattern in the Panel A (Small subsample), where the $\mathrm{H}-\mathrm{L}$ alpha difference amounts to about 34bp. Again the HML mappings are increasing in RLI. A somewhat similar decreasing pattern of the intercept is present in Panel B (Medium sized firms), but it is much weaker and none of the coefficients are significant. Still within the midcap subsample, the HML mapping is again increasing in RLI. Lastly, in Panel C (Large firms) on the two lowest RLI portfolios we see a surprising significant positive alpha as well as a strong negative mapping on the HML factor. Note that the HML factor is not significant in other portfolios of the Large group.

Results in table 8 using the OAPE proxy are consistent with our APE findings. In the E-W case, Small firms have a significant intercept increasing in RLI. A similar pattern is observed in the Mid sample, although with lower t-statistics. The Big sample does not have a clear pattern of alphas. In the V-W case, Small firms have a $\mathrm{H}-\mathrm{L}$ alpha difference of about $29 \mathrm{bp}$. However, none of the intercepts is significant in the Small and Mid samples. Again, the Large subset earns a surprising positive alpha in the two low RLI portfolios, again accompanied by strong negative HML mappings.

\subsubsection{Moving window tests}

We now try to identify the periods at which these abnormal returns are earned. Pinning down these periods should shed some light on the mechanisms at play. For example, if these returns are equally spread out over the sample period has a different meaning than if these alphas are "surprise returns" earned at some particular points in time (e.g. during downturns).

One method that allows us to obtain some answers to our questions is to run moving window regressions of value-weighted returns. We keep our annual sorting and portfolio updating frequency as in the previous cases, but we reduce the length of the time series regressions to a moving window. We chose a four year window in order to ensure a sufficient precision of estimations. We present in figure 1 the alphas and corresponding t-stats from our experience, using the APE measure as proxy for relative labor intensity. For each of the three size groups we present the top, mid, and bottom quintile RLI portfolios. 
The message from panel A is quite clear-cut. The small size/low RLI portfolio has earned the lowest, mostly negative, abnormal returns for most of our sample period. These negative returns were particularly significant during the expansionary periods of the late 1980s, late 1990s and the 2nd half of 2000s. The only exceptions with positive returns are post-recessionary periods of the early 1980s and of the 2000s. At the other extreme, small size/high RLI firms earned mostly positive returns, with most significant periods during the expansionary late 1990s and through the mid 2000s. The low labor intensity firms seem to have negative premiums due to their perceived lower risks. The high labor firms earned their premiums mostly during the 1990s and 2000s.

We also checked whether these patterns do not reflect a financing constraints story. In effect, small size/low RLI firms could be seen as capital intensive firms with more pledgeable collateral. Our results (presented in the previous chapter) using several financing constraints proxies show completely different patterns of abnormal returns over time. This excludes the hypothesis of RLI picking up financing constraints.

There are some similarities between the mid-sized firms in panel B and the small firms panel A. The low RLI portfolio in particular seems to have similar negative spikes or abnormal returns in normal periods, well in advance of recessions. The high labor intensity portfolio oscillates between positive and negative abnormal returns, which explains why on average the return was zero over the whole period.

Large firms in panel $\mathrm{C}$ have had much smaller alphas overall. The High RLI group earned zero or slightly positive alphas over most of the sample period, with only one negative spike in the late 1990s. The Low RLI group (high assets per employee) has had a similar abnormal return pattern in the early 1980s as the Low RLI groups of Small and Mid stocks. The disconnection occurred in the mid-1990s, where these firms started to earn mostly positive alphas all the way through the early 2000s. The timing of this break could indicate that it is related with the appearance of a strong population of high-tech firms in the 1990s. During that period investors required a higher returns from traditional high asset per employee firms, in excess of what their systematic risk would warrant. This lasted until the market correction of 2001 
where these abnormal returns disappeared.

There are several important points to be made from the time series analyses of portfolio returns. First, we have documented further support for H2 in the Small and, in part, the Mid-sized groups (especially with the E-W returns). The additional returns of highly labor intensive small firms were earned continuously over the sample period, and not at a particular point in time. They remain significant even after controlling for the Fama-French-Carhart factors. Second, the mappings on the HML book-to-market factor are increasing with labor intensity, but they do not completely remove the abnormal returns in E-W portfolios. Third, there seems to be a link between the mappings on the HML factor and the significance of the abnormal returns. Specifically, in several cases positive abnormal returns in regressions are accompanied by a strikingly different mapping on the HML factor. In short, portfolios sorted on RLI seem to map differently on the HML factor, as predicted on theoretical grounds (Carlson et al. (2004)). But after controlling for this HML factor mapping, a return discrepancy appears in a 4-factor model.

\subsection{Industry wage levels and the effects of labor intensity}

We discussed in section 2 three mechanisms through which labor intensity potentially affects firm risk (see hypothesis H1). We now investigate which of these mechanisms is most likely at play by separating industries based on their wage level.

Ever since Griliches (1969) it is widely accepted that capital and unskilled labor are more substitutable, whereas capital and skilled labor show complementarity effects (for more recent evidence see Bergström and Panas (1992) and Duffy et al. (2004)). Furthermore Krusell et al. (2000) show that capital-skill complementarity is central in explaining the evolution of the wage premium of skilled labor with respect to unskilled labor over the last decades. For our purposes we will assume that the industry wage level is a proxy for the importance of skilled labor and human capital within an industry. It is also likely that labor adjustment costs (e.g. searching, hiring, and reorganizing) are to some extent proportional to the wage level. High 
wage industries should therefore be also subject to higher labor adjustment costs.

We use data from the U.S. Census Local Employment Dynamics program to separate high and low wage industries. The Quarterly Workforce Indicators (QWI) provide quarterly data on average monthly worker earnings per state and two-digit SIC industry. We aggregate these state-level data to obtain a ranking of industries. For a given state and quarter we rank industries based on average worker earnings. We then average ranks across quarters and across states. $^{2}$

We split our return data in two halves by comparing the industry wage rank to the median rank of all observations. High wage industries (excluding the financial services and utilities) include 28 Chemicals, 35 Industrial machinery\&equipment, 36 Electronic\&electric equipment, and 38 Instruments. The low worker earnings industries include among others 20 Food\&kindred, 34 Fabricated metal products, 33 Primary metals, and 73 Business services. ${ }^{3}$

We present in table 9 average DGTW-adjusted returns of sorted portfolios, separating high and low wage industries. The first observation is that the effect of relative labor intensity is stronger in low wage industries. Using the APE proxy and looking at all firms, the value-weighted return differential is $17.5 \mathrm{bp} /$ month for low wage industries, while it is slightly negative at $-6.3 \mathrm{bp}$ for high wage industries. When using the OAPE proxy, the return differentials are respectively $19.5 \mathrm{bp}$ and $-2.4 \mathrm{bp}$. We note that the low-wage $\mathrm{H}-\mathrm{L}$ return is statistically significant only in the OAPE case.

A further inspection of table 9 reveals that the above effect of wage level is mostly driven by the Large subsample (>50th NYSE percentile). For the APE proxy the return differential is $18 \mathrm{bp}$ per month in low wage industries, compared to $-8 \mathrm{bp}$ in high wage industries. For the OAPE proxy the differentials are respectively $21 \mathrm{bp}$ and $-4.6 \mathrm{bp}$. The difference between the two $\mathrm{H}-\mathrm{L}$ returns, though economically relevant (about $3.1 \%$ annual), is in neither case statistically significant ( $t$-stats of 1.24 for APE and 1.27 for OAPE). Industry wages do also affect the H-L return in the Small sample. This effect disappears however (actually it slightly

\footnotetext{
${ }^{2}$ We use a sample comprising ten largest states that have sufficient historical SIC2 worker earnings data in the QWI database: California, Florida, Georgia, Illinois, Michigan, New Jersey, North Carolina, Pennsylvania, Virginia, and Texas.

${ }^{3}$ Our results are not sensitive (in fact, they are slightly improved) if we exclude the very heterogeneous industry group 73 Business services.
} 
reverses) when using the alternative proxy of labor intensity.

Our results, though statistically weak, tend to suggest that labor intensity matters relatively more in industries that use more low-skilled labor and that are more likely to face a substitutability trade-off between labor and capital. More importantly, we find no evidence indicating that labor intensity risks matter more in high wage industries. Therefore, our results cast doubt on the idea that it is labor adjustment costs that generate operating risk in labor intensive firms. Indeed, adjustment costs are more likely to be higher in high wage industries. Similarly, the human capital turnover risk is equally unlikely to be the mechanism at play, given that high-wage industries are very likely those that use more skilled labor. The only foundation of $\mathrm{H} 1$ that is not at odds with these results is the wedge between a volatile labor productivity and a relatively sticky unit wage.

\subsection{Financial leverage and labor intensity}

One objection to our results could be that operating and financing decisions are jointly determined (see MacKay and Phillips (2005)). If firms target an overall level of risk through a combination of operating risk and financial risk, empirical estimation of the marginal effects is challenging. Gomes and Schmid (2010) discuss why empirical studies of the effect of financial leverage on expected stock returns were inconclusive. As one component of risk changes (exogenously or not), firms are likely to adjust the other components and the overall effect is ambiguous. For example, Simintzi, Vig and Volpin (2010) show that firms reduce their financial risk following increases the bargaining power of labor.

We address this issue in table 10 by additionally sorting the size-RLI portfolios on book financial leverage. We define book leverage as the ratio of current and long-term debt (fields "dlc" and "dltt") to book assets (field "at"). We define three leverage groups using the 30th and the 70th percentile. As in previous cases, we set the cutoff percentiles annually at the end of June from the distribution of all but Small stocks. We only present results using the assets per employee proxy of RLI, but results using operating assets are very similar.

The excess returns and adjusted returns are increasing with labor intensity in highly lever- 
aged small firms and the $\mathrm{H}-\mathrm{L}$ return is significantly positive. The relationship is ambiguous in highly leveraged medium and large firms. At medium levels of leverage the picture is much clearer. Both excess and adjusted returns are broadly increasing with labor intensity. Although the $\mathrm{H}-\mathrm{L}$ return is significant only for Small firms, it is positive also for medium firms (a modest $4.6 \mathrm{bp} /$ month) and large firms (almost $13 \mathrm{bp} /$ month). Moreover, the L portfolios earn a negative adjusted return for all sizes at medium levels of leverage. Lastly, the effect of labor intensity is the least present in low leverage firms. The $\mathrm{H}-\mathrm{L}$ return is only positive in the small subsample, and it is not significant. In the large subsample the $\mathrm{H}-\mathrm{L}$ adjusted return is almost $-23 \mathrm{bp} /$ month (with a $t$-stat of -1.45 ).

In summary, relative labor intensity seems to affect returns positively at medium levels of financial leverage. This effect is statistically significant only in the Small subsample. At high levels of leverage the effect of labor intensity on adjusted returns is low in the Medium-size and Large subsample. The measure of relative labor intensity has an even more ambiguous effect at low levels of leverage. Arguably, firms that take on very little debt could do so because they face some other specific business risk. Our measure of labor intensity fails capture these other risks.

\section{Conclusion}

In this paper we attempt to isolate a pure effect of labor intensity on firm risk and on stock returns. We propose to measure labor intensity using two assets-per-employee variables relative to an industry normal level (measured by the SIC3 median). Based on previous literature we provide three alternative rationales for the effect of labor intensity on firm risk. First, labor adjustment costs potentially make the labor costs quasi-fixed, resulting in labor induced operating leverage. Second, given a higher volatility of labor productivity compared to unit wages, labor intensive firms face a higher operating risk even if adjustment costs are small. Third, labor intensive firms face a relatively higher worker turnover risk, exposing them to losses of human capital investments during downsizing or voluntary departures.

Our proxies capture differences in operating leverage in the small and medium-sized firms 
subsample. The results in the large firms subsample are ambiguous. As for individual stock returns, these are positively related to labor intensity, even after controlling for other firm characteristics like size, $\mathrm{B} / \mathrm{M}$ of equity, and previous returns. This relationship is again present in small and medium firms.

Portfolio returns confirm a strong effect of RLI for small firms, and an effect of RLI on equally weighted returns of mid-cap firms. In time series regressions of double sorted portfolio returns, we again find evidence for RLI effects in Small firms and Medium firms. An interesting association appears between HML mappings and excess returns: positive abnormal returns on Large firms are accompanied with a particularly strong mapping on the HML factor. Moving window analysis reveals that the Small and Mid-cap abnormal returns were spread out over the sample period, while the abnormal returns on Large firms were earned during the late 1990s' period of technological changes. One of the main findings of our paper is that the HML B/M factor seems to pick up some of the RLI differences, but still leaves some abnormal returns patterns in a 4 -factor setting.

Our further inspection of the effect of industry wage levels reveals that RLI has a stronger influence in low-wage industries. This does not speak in favor of the adjustment costs and the labor turnover rationales of the effect of RLI. The most plausible rationale is therefore the volatile productivity/sticky wages story.

Lastly, we control for the firms' likely trade-off between operating and financial risk. At medium levels of financial leverage we find a positive effect of RLI on expected returns. On the other hand, the effect of RLI is ambiguous for firms with high or low levels of debt. 


\section{References}

Bazdresch, S., F. Belo, and X. Lin (2008): "Labor Hiring, Investment and Stock Return Predictability in the Cross Section," Working paper.

Bergström, V., and E. E. Panas (1992): "How Robust is the Capital-Skill Complementarity Hypothesis?," The Review of Economics and Statistics, 74(3), 540-546.

Carlson, M., A. Fisher, and R. Giammarino (2004): "Corporate Investment and Asset Price Dynamics: Implications for the Cross-Section of Returns," Journal of Finance, 59(6), $2577-2603$.

Chen, H., M. Kacperczyk, and H. Ortiz-Molina (2011): "Labor Unions, Operating Flexibility, and the Cost of Equity," Journal of Financial and Quantitative Analysis, 46(1), $25-58$.

Daniel, K., M. Grinblatt, S. Titman, and R. Wermers (1997): "Measuring Mutual Fund Performance with Characteristic-Based Benchmarks," Journal of Finance, 52(3), 10351058.

Danthine, J.-P., and J. B. Donaldson (2002): "Labour Relations and Asset Returns," Review of Economic Studies, 69(1), 41-64.

Donangelo, A. (2011): "Labor Mobility and the Cross-Section of Expected Return," Working paper.

Duffy, J., C. Papageorgiou, and F. Perez-Sebastian (2004): "Capital-Skill Complementarity? Evidence from a Panel of Countries," The Review of Economics and Statistics, 86(1), 327-344.

Fama, E. F., and K. R. French (2008): "Dissecting Anomalies," Journal of Finance, 63(4), $1653-1678$.

Gomes, J. F., And L. Schmid (2010): "Levered Returns," Journal of Finance, 65(2), 467-494.

Gourio, F. (2007): "Labor Leverage, Firms' Heterogeneous Sensitivities to the Business Cycle, and the Cross-Section of Expected Returns," Working paper.

Griliches, Z. (1969): "Capital-Skill Complementarity," The Review of Economics and Statistics, 51(4), 465-468.

Krusell, P., L. E. Ohanian, J. RÃos-Rull, and G. L. Violante (2000): "CapitalSkill Complementarity and Inequality: A Macroeconomic Analysis," Econometrica, 68(5), 1029-1053.

Lev, B. (1974): "On the Association Between Operating Leverage and Risk," Journal of Financial and Quantitative Analysis, 9(4), 627-641.

MacKay, P., And G. M. Phillips (1997): "How Does Industry Affect Firm Financial Structure?," The Review of Financial Studies, 18(4), 1433-1466. 
Mandelker, G. N., and S. G. Rhee (1984): "The Impact of the Degrees of Operating and Financial Leverage on Systematic Risk of Common Stock," Journal of Financial and Quantitative Analysis, 19(1), 45-57.

Merz, M., And E. Yashiv (2007): "Labor and the Market Value of the Firm," American Economic Review, 97(4), 1419-1431.

Penman, S. H., S. A. Richardson, and I. Tuna (2007): "The Book-to-Price Effect in Stock Returns: Accounting for Leverage," Journal of Accounting Research, 45(2), 427-467.

Simintzi, E., V. Vig, and P. F. Volpin (2010): "Labor and Capital: Is Debt a Bargaining Tool?," Working paper.

Skoulakis, G. (2008): "Panel Data Inference in Finance: Least-Squares vs Fama-MacBeth," Working paper.

Wermers, R. (2004): "Is Money Really "Smart"? New Evidence on the Relation Between Mutual Fund Flows, Manager Behavior, and Performance Persistence," Working paper. 
Table 1: Descriptive statistics

Descriptive statistics of U.S. firms from the merged Compustat-CRSP database that satisfy our selection criteria. Assets and market capitalization are in millions of constant 1994 dollars. We use the CPI to deflate dollar series. ROA is earnings before extraordinary items and interest over total assets. Employees are in thousands. Panel A presents all firm-years over 1975-2009. Panels B, C, and D present statistics for the top, middle and bottom quintile groups of firm-years sorted on relative labor intensity. We use the inverse of previous year's assets per employee minus the SIC3 median as proxy of RLI: labor intensive firms have low assets per employee relative to the SIC3 median.

\begin{tabular}{|c|c|c|c|c|c|}
\hline & Mean & $\mathrm{SD}$ & $25 \operatorname{th} \%$ & $50 \operatorname{th} \%$ & $75 \operatorname{th} \%$ \\
\hline \multicolumn{6}{|c|}{ Panel A: All firms (81953 obs.) } \\
\hline Assets (const. \$mil.) & 1606.2 & 9649.3 & 54.8 & 169.0 & 640.7 \\
\hline Market cap. (const. \$mil.) & 1654.6 & 9180.2 & 42.1 & 150.2 & 641.6 \\
\hline ROA & 0.030 & 0.149 & 0.015 & 0.067 & 0.104 \\
\hline $\mathrm{M} / \mathrm{B}$ assets & 1.707 & 1.235 & 0.991 & 1.300 & 1.927 \\
\hline Real sales growth & 0.131 & 0.389 & -0.041 & 0.058 & 0.197 \\
\hline Capex/Assets & 0.069 & 0.073 & 0.024 & 0.048 & 0.087 \\
\hline Employees (000s) & 9.2 & 38.8 & 0.4 & 1.3 & 5.0 \\
\hline \multicolumn{6}{|c|}{ Panel B: Labor intensity sorted, Lowest quintile group } \\
\hline Assets (const. \$mil.) & 2589.2 & 17200.6 & 62.2 & 193.5 & 743.3 \\
\hline ROA & 0.007 & 0.176 & -0.017 & 0.057 & 0.101 \\
\hline Real sales growth & 0.208 & 0.525 & -0.049 & 0.086 & 0.300 \\
\hline Capex/Assets & 0.065 & 0.082 & 0.015 & 0.036 & 0.080 \\
\hline \multicolumn{6}{|c|}{ Panel C: Labor intensity sorted, 3rd quintile group } \\
\hline Assets (const. \$mil.) & 1679.1 & 7774.9 & 71.7 & 228.6 & 899.5 \\
\hline ROA & 0.040 & 0.136 & 0.027 & 0.071 & 0.104 \\
\hline Real sales growth & 0.109 & 0.335 & -0.036 & 0.053 & 0.172 \\
\hline Capex/Assets & 0.068 & 0.066 & 0.027 & 0.050 & 0.087 \\
\hline \multicolumn{6}{|c|}{ Panel D: Labor intensity sorted, Highest quintile group } \\
\hline Assets (const. \$mil.) & 661.6 & 3294.3 & 36.0 & 91.5 & 296.6 \\
\hline ROA & 0.042 & 0.129 & 0.021 & 0.069 & 0.106 \\
\hline Real sales growth & 0.108 & 0.329 & -0.042 & 0.054 & 0.181 \\
\hline Capex/Assets & 0.074 & 0.076 & 0.029 & 0.052 & 0.092 \\
\hline
\end{tabular}


Table 2: Operating leverage and relative labor intensity

We regress firms' annual change of log operating earnings after depreciation on the change of log sales and a constant (not presented). We independently sort firms based on previous year's size and relative labor intensity (RLI). Size groups are defined using the 20th and 50th NYSE market capitalization percentiles. RLI is proxied in panel A by assets per employee relative to the SIC3 median (Rel. APE $=\mathrm{APE} / \mathrm{APE}^{\mathrm{SIC} 3}-1$ ). Panel B uses operating assets per employee instead. We sort firms into five RLI groups based on previous year's quintiles. $\mathrm{H}$ (L) is the $20 \%$ of firm-years with the highest (lowest) RLI i.e. the least (most) assets per employee in year $t-1$. For each size-RLI group we run a separate Fama-MacBeth procedure (running accross firms). We use Compustat financial data covering the period 1975 to 2009.

\begin{tabular}{|c|c|c|c|c|c|}
\hline & $\mathrm{H}$ & RLI4 & RLI3 & RLI2 & $\mathrm{L}$ \\
\hline \multicolumn{6}{|c|}{$\begin{array}{c}\text { Panel A: APE } \\
\text { Small firms }\end{array}$} \\
\hline$\Delta \ln ($ Sales $)$ & $\begin{array}{l}2.247^{* * *} \\
(15.42)\end{array}$ & $\begin{array}{l}2.280^{* * *} \\
(14.22)\end{array}$ & $\begin{array}{l}2.381^{* * *} \\
(15.09)\end{array}$ & $\begin{array}{l}1.999^{* * *} \\
(11.76)\end{array}$ & $\begin{array}{l}1.646^{* * *} \\
(7.93)\end{array}$ \\
\hline Avg. $R^{2}$ & 0.152 & 0.157 & 0.174 & 0.216 & 0.258 \\
\hline \multicolumn{6}{|c|}{ Medium-sized firms } \\
\hline$\Delta \ln ($ Sales $)$ & $\begin{array}{l}1.843^{* * *} \\
(12.26)\end{array}$ & $\begin{array}{l}2.152^{* * *} \\
(9.54)\end{array}$ & $\begin{array}{l}1.680^{* * *} \\
(9.09)\end{array}$ & $\begin{array}{l}1.721^{* * *} \\
(12.26)\end{array}$ & $\begin{array}{l}1.785^{* * *} \\
(12.68)\end{array}$ \\
\hline Avg. $R^{2}$ & 0.202 & 0.212 & 0.160 & 0.230 & 0.274 \\
\hline \multicolumn{6}{|c|}{ Big firms } \\
\hline$\Delta \ln ($ Sales $)$ & $\begin{array}{l}1.349^{* * *} \\
(8.45)\end{array}$ & $\begin{array}{l}1.721^{* * *} \\
(17.19)\end{array}$ & $\begin{array}{l}1.904^{* * *} \\
(16.23)\end{array}$ & $\begin{array}{l}1.856^{* * *} \\
(18.79)\end{array}$ & $\begin{array}{l}1.654^{* * *} \\
(17.01)\end{array}$ \\
\hline Avg. $R^{2}$ & 0.227 & 0.253 & 0.230 & 0.285 & 0.306 \\
\hline \multicolumn{6}{|c|}{ Panel B: OAPE } \\
\hline$\Delta \ln ($ Sales $)$ & $\begin{array}{l}2.104^{* * *} \\
(13.58)\end{array}$ & $\begin{array}{l}2.405^{* * *} \\
(15.98)\end{array}$ & $\begin{array}{l}2.495^{* * *} \\
(14.93)\end{array}$ & $\begin{array}{l}2.083^{* * *} \\
(11.60)\end{array}$ & $\begin{array}{l}1.733^{* * *} \\
(12.64)\end{array}$ \\
\hline$R^{2}$ & 0.152 & 0.177 & 0.190 & 0.198 & 0.256 \\
\hline \multicolumn{6}{|c|}{ Medium-sized firms } \\
\hline$\Delta \ln$ (Sales) & $\begin{array}{l}1.571^{* * *} \\
(11.19)\end{array}$ & $\begin{array}{l}2.193^{* * *} \\
(12.19)\end{array}$ & $\begin{array}{l}1.672^{\text {*** }} \\
(10.49)\end{array}$ & $\begin{array}{l}1.717^{* * *} \\
(11.81)\end{array}$ & $\begin{array}{l}1.836^{* * *} \\
(12.19)\end{array}$ \\
\hline$R^{2}$ & 0.197 & 0.223 & 0.143 & 0.246 & 0.256 \\
\hline \multicolumn{6}{|c|}{ Big firms } \\
\hline$\Delta \ln ($ Sales $)$ & $\begin{array}{l}1.195^{* * *} \\
(6.60)\end{array}$ & $\begin{array}{l}1.790^{* * *} \\
(13.28)\end{array}$ & $\begin{array}{l}1.884^{* * *} \\
(15.10)\end{array}$ & $\begin{array}{l}1.730^{* * *} \\
(14.49)\end{array}$ & $\begin{array}{l}1.779^{* * *} \\
(19.27)\end{array}$ \\
\hline$R^{2}$ & 0.197 & 0.247 & 0.233 & 0.269 & 0.301 \\
\hline
\end{tabular}


Table 3: Individual stock returns and relative labor intensity

We run monthly Fama-MacBeth regressions of stock returns on firm-level characteristics. Relative labor intensity is proxied by the inverse of assets per employee (Panel A) and operating assets per employee (Panel B), measured relative to the SIC3 median (Rel. $\left.\mathrm{APE}=\mathrm{APE} / \mathrm{APE}^{\mathrm{SIC} 3}-1\right)$. High labor intensity corresponds to low APE/OAPE. Size is the log of market capitalization, B/M is the log of the December book to market equity, Mom2-12 is momentum i.e. the cumulative continuous return over the months $t-12$ to $t-2$. Observations of RHS variables for July $t$ to June $t+1$ are taken as of June $t$, except Mom2-12 which is measured monthly. All variables are winsorized at the upper and lower $1 \%$. Stock returns are from the CRSP Merged database. Regressions are estimated on the period July 1976 to December 2009, with an average cross-section of 1,754 firms. We present average estimates and their t-statistics based on Newey-West adjusted SEs (4 lags).

(1)

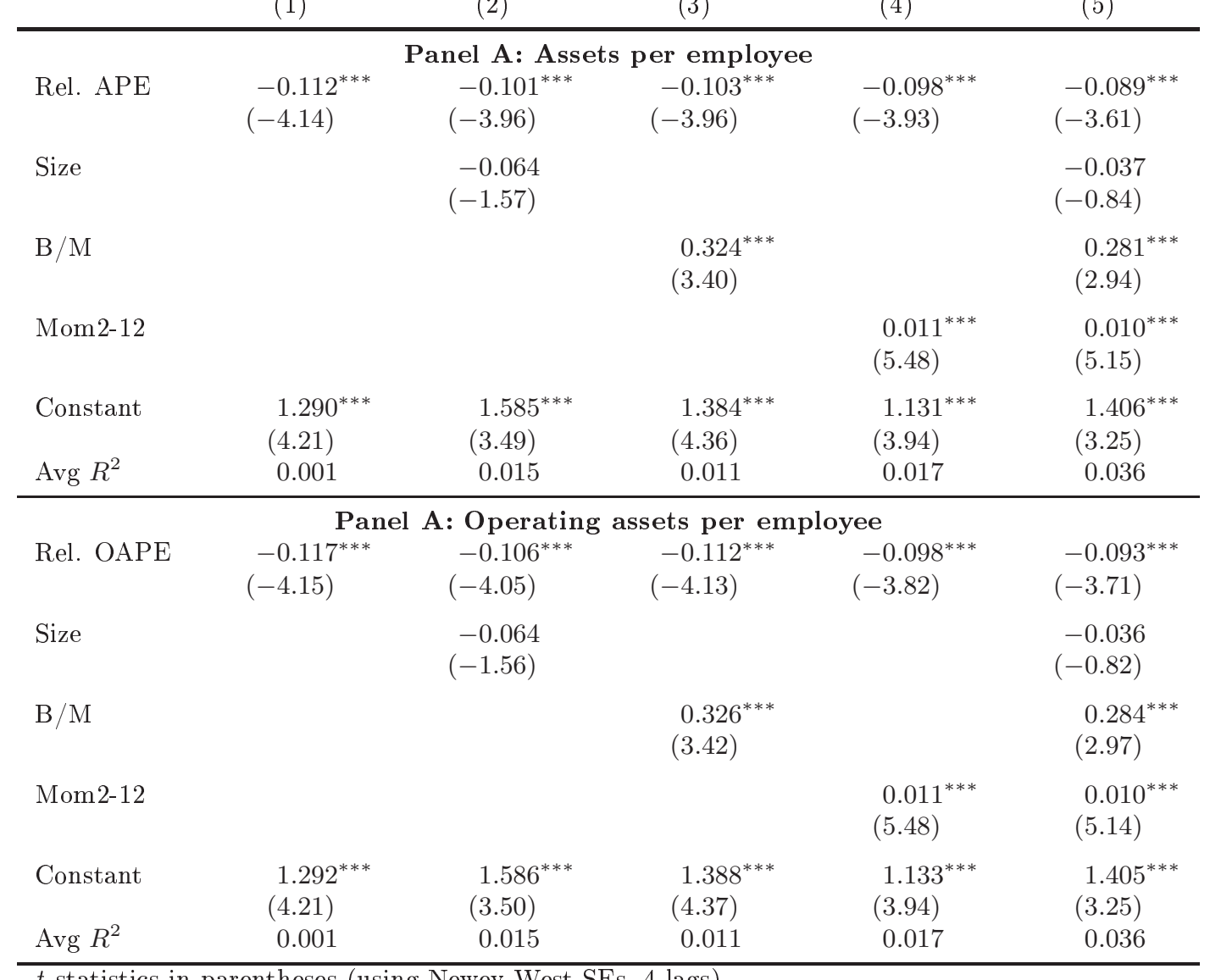

$t$ statistics in parentheses (using Newey-West SEs, 4 lags)

${ }^{*} p<0.10,{ }^{* *} p<0.05,{ }^{* * *} p<0.01$ 
Table 4: Individual stock returns and relative labor intensity in size subsamples

We run monthly Fama-MacBeth regressions of stock returns on firm-level determinants separately for Small, Medium and Big firms. At the end of June of year $t$ we define three size groups using the 20th and 50th NYSE percentile and keep these assignments for July $t$ to June $t+1$. Relative labor intensity is proxied by assets per employee measured relative to the SIC3 median (Rel. APE $=$ APE/APE $\left.{ }^{\mathrm{SIC} 3}-1\right)$, Size is the $\log$ of market capitalization, B/M is the log of the December book to market equity, Mom2-12 is momentum i.e. the cumulative continuous return over the months $t-12$ to $t-2$. Observations of RHS variables for July $t$ to June $t+1$ are taken as of June $t$, except Mom2-12 which is measured monthly. All variables are winsorized at the upper and lower 1\%. Stock returns are from the CRSP Merged database. Regressions are estimated on the period July 1976 to December 2009. We present average estimates and their t-statistics based on Newey-West adjusted SEs (4 lags).

\begin{tabular}{lccc}
\hline & $(1)$ & $(2)$ & $(3)$ \\
& Small & Medium & Large \\
\hline Rel. APE & $-0.113^{* * *}$ & $-0.073^{*}$ & -0.028 \\
& $(-3.95)$ & $(-1.71)$ & $(-0.72)$ \\
Size & -0.067 & 0.020 & -0.053 \\
& $(-1.00)$ & $(0.24)$ & $(-1.05)$ \\
B/M & $0.296^{* * *}$ & $0.272^{* *}$ & 0.139 \\
& $(2.88)$ & $(2.44)$ & $(1.39)$ \\
Mom2-12 & $0.011^{* * *}$ & $0.010^{* * *}$ & $0.007^{* *}$ \\
& $(6.25)$ & $(3.76)$ & $(2.49)$ \\
Constant & $1.549^{* * *}$ & $1.077^{*}$ & $1.399^{* *}$ \\
& $(3.54)$ & $(1.80)$ & $(2.52)$ \\
\hline Avg obs. & 895 & 409 & 450 \\
Avg $R^{2}$ & 0.027 & 0.042 & 0.068 \\
\hline
\end{tabular}

$t$ statistics in parentheses

${ }^{*} p<0.10,{ }^{* *} p<0.05,{ }^{* * *} p<0.01$ 
Table 5: Average returns of double-sorted portfolios by size and relative labor intensity $(\mathrm{APE})$

We construct portfolios at the end of June of year $t$ by independently sorting firms by market capitalization and by relative labor intensity (RLI). We use these sorts to calculate July $t$ to June $t+1$ returns. Size groups are defined using the 20th and 50th NYSE market capitalization percentiles. Relative labor intensity is proxied by assets per employee, measured relative to the SIC3 median (Rel. APE $=\mathrm{APE} / \mathrm{APE}^{\mathrm{SIC} 3}-1$ ). We sort firms into five groups based on the year $t-1$ RLI distribution quintiles excluding small firms. H (L) is the $20 \%$ of observations with the highest (lowest) RLI i.e. the least (most) assets per employee in year $t-1$. The t-stats are based on Newey-West SEs using 4 lags. We calculate excess returns against the risk-free rate (Kenneth French data) and DGTW-adjusted returns (following Daniel et al. (1997), using Russ Wermers data). Stock returns are from the Compustat CRSP Merged database, covering the period July 1976 to December 2009 (402 monthly observations).

\begin{tabular}{|c|c|c|c|c|c|c|c|}
\hline & \multicolumn{2}{|c|}{ Excess returns } & \multicolumn{2}{|c|}{ DGTW-adj. returns } & \multirow{2}{*}{$\begin{array}{c}\text { Avg. } \\
\text { \# firms }\end{array}$} & \multirow{2}{*}{$\begin{array}{l}\text { Avg. } \\
\text { ME }\end{array}$} & \multirow{2}{*}{$\begin{array}{c}\text { Avg. } \\
\text { BE/ME }\end{array}$} \\
\hline & VW & EW & VW & EW & & & \\
\hline \multicolumn{8}{|c|}{ Panel A: All firms } \\
\hline $\mathrm{H}$ & 0.558 & 1.087 & 0.039 & 0.317 & 555 & 865.5 & 0.497 \\
\hline RLI4 & 0.601 & 1.025 & 0.038 & 0.257 & 400 & 1430.5 & 0.562 \\
\hline RLI3 & 0.416 & 0.938 & -0.075 & 0.196 & 345 & 1990.1 & 0.587 \\
\hline RLI2 & 0.551 & 0.861 & 0.030 & 0.126 & 347 & 2533.1 & 0.555 \\
\hline $\mathrm{L}$ & 0.468 & 0.749 & -0.007 & 0.066 & 354 & 2872.7 & 0.504 \\
\hline $\mathrm{H}-\mathrm{L}$ & 0.089 & 0.338 & 0.046 & 0.252 & & & \\
\hline$t$-stat & $(0.623)$ & $(3.735)$ & $(0.520)$ & $(3.058)$ & & & \\
\hline \multicolumn{8}{|c|}{ Panel B: Small size } \\
\hline $\mathrm{H}$ & 1.009 & 1.289 & 0.190 & 0.423 & 368 & 65.8 & 0.766 \\
\hline RLI4 & 1.050 & 1.302 & 0.198 & 0.435 & 207 & 77.0 & 0.837 \\
\hline RLI3 & 1.024 & 1.177 & 0.162 & 0.288 & 162 & 79.4 & 0.867 \\
\hline RLI2 & 0.936 & 1.072 & 0.112 & 0.211 & 159 & 81.9 & 0.864 \\
\hline $\mathrm{L}$ & 0.651 & 0.949 & -0.134 & 0.130 & 168 & 83.2 & 0.880 \\
\hline $\mathrm{H}-\mathrm{L}$ & 0.358 & 0.340 & 0.324 & 0.293 & & & \\
\hline$t$-stat & $(3.203)$ & $(3.410)$ & $(2.961)$ & $(2.957)$ & & & \\
\hline \multicolumn{8}{|c|}{ Panel C: Medium size } \\
\hline $\mathrm{H}$ & 0.771 & 0.863 & 0.032 & 0.134 & 106 & 425.3 & 0.747 \\
\hline RLI4 & 0.841 & 0.856 & 0.045 & 0.071 & 99 & 435.8 & 0.632 \\
\hline RLI3 & 0.877 & 0.918 & 0.147 & 0.183 & 86 & 440.3 & 0.643 \\
\hline RLI2 & 0.743 & 0.793 & -0.004 & 0.034 & 81 & 440.1 & 0.657 \\
\hline $\mathrm{L}$ & 0.795 & 0.721 & 0.074 & 0.009 & 87 & 442.4 & 0.614 \\
\hline $\mathrm{H}-\mathrm{L}$ & -0.024 & 0.142 & -0.042 & 0.125 & & & \\
\hline$t$-stat & $(-0.164)$ & $(1.042)$ & $(-0.330)$ & $(1.067)$ & & & \\
\hline \multicolumn{8}{|c|}{ Panel D: Large size } \\
\hline $\mathrm{H}$ & 0.540 & 0.682 & 0.034 & 0.087 & 81 & 5312.7 & 0.459 \\
\hline RLI4 & 0.576 & 0.683 & 0.034 & 0.061 & 94 & 5558.9 & 0.551 \\
\hline RLI3 & 0.395 & 0.645 & -0.088 & 0.052 & 96 & 6694.2 & 0.579 \\
\hline RLI2 & 0.546 & 0.680 & 0.032 & 0.079 & 107 & 7770.7 & 0.547 \\
\hline $\mathrm{L}$ & 0.474 & 0.649 & -0.001 & 0.052 & 99 & 9425.2 & 0.496 \\
\hline $\mathrm{H}-\mathrm{L}$ & 0.066 & 0.033 & 0.035 & 0.035 & & & \\
\hline$t$-stat & $(0.429)$ & $(0.277)$ & $(0.366)$ & $(0.349)$ & & & \\
\hline
\end{tabular}


Table 6: Average returns of double-sorted portfolios by size and relative labor intensity (OAPE)

We construct portfolios at the end of June of year $t$ by independently sorting firms by market capitalization and by relative labor intensity (RLI). We use these sorts to calculate July $t$ to June $t+1$ returns. Size groups are defined using the 20th and 50th NYSE market capitalization percentiles. Relative labor intensity is proxied by operating assets per employee, measured relative to the SIC3 median (Rel. OAPE $=$ OAPE/OAPESIC3 -1$)$. We sort firms into five groups based on the year $t-1$ RLI distribution quintiles. H (L) is the $20 \%$ of firm-years with the highest (lowest) RLI i.e. the least (most) op. assets per employee in year $t-1$. The t-stats are based on Newey-West SEs using 4 lags. We calculate excess returns against the risk-free rate (Kenneth French data) and DGTW-adjusted returns (following Daniel et al. (1997), using Russ Wermers data). Stock returns are from the Compustat CRSP Merged database, covering the period July 1976 to December 2009 (402 monthly observations).

\begin{tabular}{|c|c|c|c|c|c|c|c|}
\hline & \multicolumn{2}{|c|}{ Excess returns } & \multicolumn{2}{|c|}{ DGTW adj. returns } & \multirow{2}{*}{$\begin{array}{c}\text { Avg. } \\
\text { \# firms }\end{array}$} & \multirow{2}{*}{$\begin{array}{l}\text { Avg. } \\
\text { ME }\end{array}$} & \multirow{2}{*}{$\begin{array}{c}\text { Avg. } \\
\text { BE/ME }\end{array}$} \\
\hline & VW & EW & VW & EW & & & \\
\hline \multicolumn{8}{|c|}{ Panel A: All firms } \\
\hline $\mathrm{H}$ & 0.521 & 1.078 & 0.021 & 0.318 & 568 & 639.8 & 0.526 \\
\hline RLI4 & 0.560 & 1.016 & 0.042 & 0.254 & 403 & 1187.7 & 0.526 \\
\hline RLI3 & 0.516 & 0.937 & -0.007 & 0.195 & 349 & 1747.2 & 0.637 \\
\hline RLI2 & 0.556 & 0.916 & 0.002 & 0.175 & 337 & 2840.4 & 0.554 \\
\hline $\mathrm{L}$ & 0.434 & 0.718 & -0.036 & 0.021 & 344 & 3714.2 & 0.484 \\
\hline $\mathrm{H}-\mathrm{L}$ & 0.087 & 0.360 & 0.057 & 0.298 & & & \\
\hline$t$-stat & 0.696 & 4.426 & 0.707 & 4.265 & & & . \\
\hline \multicolumn{8}{|c|}{ Panel B: Small size } \\
\hline $\mathrm{H}$ & 1.018 & 1.291 & 0.209 & 0.434 & 380 & 68.1 & 0.748 \\
\hline RLI4 & 1.061 & 1.264 & 0.212 & 0.386 & 213 & 76.6 & 0.830 \\
\hline RLI3 & 0.932 & 1.161 & 0.072 & 0.281 & 164 & 78.0 & 0.884 \\
\hline RLI2 & 0.930 & 1.166 & 0.108 & 0.312 & 149 & 83.2 & 0.883 \\
\hline $\mathrm{L}$ & 0.690 & 0.913 & -0.124 & 0.075 & 158 & 81.3 & 0.903 \\
\hline $\mathrm{H}-\mathrm{L}$ & 0.329 & 0.378 & 0.333 & 0.359 & & & \\
\hline$t$-stat & 2.676 & 3.852 & 2.831 & 3.710 & & & . \\
\hline \multicolumn{8}{|c|}{ Panel C: Medium size } \\
\hline $\mathrm{H}$ & 0.745 & 0.827 & 0.025 & 0.118 & 112 & 417.0 & 0.726 \\
\hline RLI4 & 0.872 & 0.910 & 0.084 & 0.131 & 99 & 438.0 & 0.628 \\
\hline RLI3 & 0.891 & 0.920 & 0.158 & 0.177 & 89 & 445.8 & 0.637 \\
\hline RLI2 & 0.804 & 0.821 & 0.017 & 0.039 & 79 & 443.5 & 0.660 \\
\hline $\mathrm{L}$ & 0.708 & 0.648 & -0.001 & -0.061 & 80 & 444.6 & 0.639 \\
\hline $\mathrm{H}-\mathrm{L}$ & 0.036 & 0.178 & 0.026 & 0.179 & & & \\
\hline$t$-stat & 0.282 & 1.388 & 0.226 & 1.571 & & & . \\
\hline \multicolumn{8}{|c|}{ Panel D: Large size } \\
\hline $\mathrm{H}$ & 0.484 & 0.633 & 0.012 & 0.029 & 75 & 3972.2 & 0.484 \\
\hline RLI4 & 0.527 & 0.666 & 0.031 & 0.080 & 91 & 4594.3 & 0.507 \\
\hline RLI3 & 0.497 & 0.665 & -0.020 & 0.066 & 96 & 5922.8 & 0.635 \\
\hline RLI2 & 0.551 & 0.732 & 0.003 & 0.119 & 109 & 8224.7 & 0.547 \\
\hline $\mathrm{L}$ & 0.431 & 0.622 & -0.034 & 0.021 & 106 & 10887.5 & 0.475 \\
\hline $\mathrm{H}-\mathrm{L}$ & 0.053 & 0.011 & 0.046 & 0.008 & & & \\
\hline$t$-stat & 0.405 & 0.120 & 0.488 & 0.091 & & & . \\
\hline
\end{tabular}


Table 7: Time-series regressions of double-sorted portfolios by size and relative labor intensity (APE)

We construct portfolios at the end of June of year $t$ by independently sorting firms by market capitalization and by relative labor intensity (RLI). We use these sorts to calculate July $t$ to June $t+1$ returns. The three size groups are defined using the 20th and 50th NYSE market capitalization percentiles. Relative abor intensity is proxied by assets per employee, measured relative to the SIC3 median (Rel. APE $=$ APE/APE ${ }^{\text {SIC3 }}-1$ ). We sort firms into five groups based on the year $t-1$ RLI distribution quintiles excluding small firms. H (L) is the $20 \%$ of observations with the highest (lowest) RLI i.e. the least (most) assets per employee in year $t-1$. The explanatory variables are from Kenneth French's webpage: Mkt- $\mathrm{R}_{\mathrm{f}}$ is the market excess return, SMB is the small minus big return, HML is the high minus low B/M return, MOM is the momentum factor. Stock returns are from the CRSP Merged database. Regressions are estimated on the period July 1976 to December 2009, i.e. 402 monthly observations. We present t-statistics using Newey-West standard errors with 4 lags.

\begin{tabular}{|c|c|c|c|c|c|c|c|c|c|c|}
\hline & \multicolumn{5}{|c|}{ Equally-weighted portfolio returns } & \multicolumn{5}{|c|}{ Value-weighted portfolio returns } \\
\hline & $\mathrm{H}$ & RLI4 & RLI3 & RLI2 & $\mathrm{L}$ & $\mathrm{H}$ & RLI4 & RLI3 & RLI2 & $\mathrm{L}$ \\
\hline & \multicolumn{10}{|c|}{ Panel A: Small size } \\
\hline Mkt- $R_{f}$ & $\begin{array}{l}0.949^{* * *} \\
(22.69)\end{array}$ & $\begin{array}{c}0.953^{* * *} \\
(23.31)\end{array}$ & $\begin{array}{l}1.030^{* * * *} \\
(23.56)\end{array}$ & $\begin{array}{l}1.003^{* * *} \\
(26.96)\end{array}$ & $\begin{array}{l}0.979^{* * *} \\
(20.79)\end{array}$ & $\begin{array}{l}1.007^{* * *} \\
(40.11)\end{array}$ & $\begin{array}{l}1.020^{* * *} \\
(39.22)\end{array}$ & $\begin{array}{l}1.072^{* * *} \\
(30.82)\end{array}$ & $\begin{array}{l}0.987^{* * *} \\
(31.99)\end{array}$ & $\begin{array}{l}1.025^{* * *} \\
(27.56)\end{array}$ \\
\hline SMB & $\begin{array}{l}1.082^{* * * *} \\
(13.86)\end{array}$ & $\begin{array}{l}1.128^{* * *} \\
(16.10)\end{array}$ & $\begin{array}{l}1.086^{* * * *} \\
(13.90)\end{array}$ & $\begin{array}{l}1.247^{* * * *} \\
(19.79)\end{array}$ & $\begin{array}{l}1.145^{* * *} \\
(13.11)\end{array}$ & $\begin{array}{l}1.139^{* * *} \\
(29.93)\end{array}$ & $\begin{array}{l}1.248^{* * * *} \\
(29.71)\end{array}$ & $\begin{array}{c}1.114^{* * * *} \\
(15.62)\end{array}$ & $\begin{array}{l}1.430^{* * *} \\
(17.36)\end{array}$ & $\begin{array}{l}1.126^{* * *} \\
(16.88)\end{array}$ \\
\hline HML & $\begin{array}{l}0.181^{* *} \\
(2.27)\end{array}$ & $\begin{array}{l}0.161^{* *} \\
(2.05)\end{array}$ & $\begin{array}{l}0.255^{* * *} \\
(3.10)\end{array}$ & $\begin{array}{l}0.154^{*} \\
(1.94)\end{array}$ & $\begin{array}{r}0.121 \\
(1.31)\end{array}$ & $\begin{array}{l}0.190^{* * *} \\
(4.75)\end{array}$ & $\begin{array}{l}0.162^{* * *} \\
(3.38)\end{array}$ & $\begin{array}{l}0.222^{* * *} \\
(4.09)\end{array}$ & $\begin{array}{l}0.112^{*} \\
(1.95)\end{array}$ & $\begin{array}{c}0.117^{*} \\
(1.71)\end{array}$ \\
\hline MOM & $\begin{array}{l}-0.213^{* * *} \\
(-3.25)\end{array}$ & $\begin{array}{l}-0.230^{* * *} \\
(-4.01)\end{array}$ & $\begin{array}{l}-0.267^{* * *} \\
(-4.15)\end{array}$ & $\begin{array}{l}-0.179^{* * *} \\
(-3.81)\end{array}$ & $\begin{array}{l}-0.189^{* * *} \\
(-3.34)\end{array}$ & $\begin{array}{c}-0.049 \\
(-1.52)\end{array}$ & $\begin{array}{l}-0.021 \\
(-0.68)\end{array}$ & $\begin{array}{l}-0.118^{* *} \\
(-2.33)\end{array}$ & $\begin{array}{c}0.032 \\
(0.74)\end{array}$ & $\begin{array}{l}-0.050 \\
(-1.15)\end{array}$ \\
\hline Constant & $\begin{array}{l}0.606^{* * *} \\
(3.74)\end{array}$ & $\begin{array}{l}0.624^{* * *} \\
(3.98)\end{array}$ & $\begin{array}{l}0.462^{* * *} \\
(2.87)\end{array}$ & $\begin{array}{l}0.303^{* *} \\
(2.01)\end{array}$ & $\begin{array}{c}0.238 \\
(1.49)\end{array}$ & $\begin{array}{c}0.160^{*} \\
(1.77)\end{array}$ & $\begin{array}{r}0.155 \\
(1.47)\end{array}$ & $\begin{array}{r}0.185 \\
(1.46)\end{array}$ & $\begin{array}{l}-0.010 \\
(-0.09)\end{array}$ & $\begin{array}{l}-0.177 \\
(-1.51)\end{array}$ \\
\hline \multicolumn{11}{|c|}{ Panel B: Medium size } \\
\hline Mkt- $R_{f}$ & $\begin{array}{l}1.075^{* * *} \\
(37.66)\end{array}$ & $\begin{array}{l}1.104^{* * *} \\
(39.34)\end{array}$ & $\begin{array}{l}1.107^{* * *} \\
(45.93)\end{array}$ & $\begin{array}{l}1.165^{* * *} \\
(43.56)\end{array}$ & $\begin{array}{l}1.160^{* * *} \\
(39.40)\end{array}$ & $\begin{array}{l}1.054^{* * *} \\
(33.85)\end{array}$ & $\begin{array}{l}1.072^{* * *} \\
(50.17)\end{array}$ & $\begin{array}{l}1.069^{* * *} \\
(48.95)\end{array}$ & $\begin{array}{l}1.137^{* * *} \\
(46.39)\end{array}$ & $\begin{array}{l}1.142^{* * * *} \\
(38.82)\end{array}$ \\
\hline SMB & $\begin{array}{l}0.779^{* * *} \\
(8.26)\end{array}$ & $\begin{array}{l}0.819^{* * * *} \\
(10.36)\end{array}$ & $\begin{array}{l}0.797^{* * *} \\
(9.62)\end{array}$ & $\begin{array}{l}0.840^{* * * *} \\
(10.81)\end{array}$ & $\begin{array}{l}0.941^{* * * *} \\
(14.04)\end{array}$ & $\begin{array}{l}0.722^{* * *} \\
(7.72)\end{array}$ & $\begin{array}{l}0.820^{* * *} \\
(14.50)\end{array}$ & $\begin{array}{l}0.808^{* * *} \\
(14.98)\end{array}$ & $\begin{array}{l}0.814^{* * *} \\
(15.86)\end{array}$ & $\begin{array}{l}1.014^{* * * *} \\
(19.87)\end{array}$ \\
\hline HML & $\begin{array}{l}0.146^{* *} \\
(2.33)\end{array}$ & $\begin{array}{l}0.190^{* * *} \\
(3.80)\end{array}$ & $\begin{array}{l}0.230^{* * *} \\
(3.51)\end{array}$ & $\begin{array}{r}0.075 \\
(1.19)\end{array}$ & $\begin{array}{l}-0.051 \\
(-0.55)\end{array}$ & $\begin{array}{c}0.133^{*} \\
(1.78)\end{array}$ & $\begin{array}{l}0.232^{* * *} \\
(4.01)\end{array}$ & $\begin{array}{l}0.187^{* * *} \\
(3.00)\end{array}$ & $\begin{array}{r}0.101 \\
(1.22)\end{array}$ & $\begin{array}{l}-0.060 \\
(-0.57)\end{array}$ \\
\hline MOM & $\begin{array}{l}-0.158^{* * *} \\
(-4.52)\end{array}$ & $\begin{array}{l}-0.207^{* * *} \\
(-4.71)\end{array}$ & $\begin{array}{l}-0.171^{* * *} \\
(-4.56)\end{array}$ & $\begin{array}{l}-0.219^{* * *} \\
(-6.35)\end{array}$ & $\begin{array}{l}-0.154^{* * *} \\
(-3.05)\end{array}$ & $\begin{array}{l}-0.017 \\
(-0.43)\end{array}$ & $\begin{array}{l}-0.035 \\
(-1.10)\end{array}$ & $\begin{array}{l}-0.025 \\
(-0.83)\end{array}$ & $\begin{array}{l}-0.044 \\
(-0.97)\end{array}$ & $\begin{array}{l}-0.008 \\
(-0.13)\end{array}$ \\
\hline Constant & $\begin{array}{c}0.168^{*} \\
(1.88)\end{array}$ & $\begin{array}{c}0.155 \\
(1.51)\end{array}$ & $\begin{array}{c}0.181^{*} \\
(1.77)\end{array}$ & $\begin{array}{c}0.105 \\
(1.08)\end{array}$ & $\begin{array}{c}0.008 \\
(0.06)\end{array}$ & $\begin{array}{r}0.005 \\
(0.06)\end{array}$ & $\begin{array}{r}0.017 \\
(0.19)\end{array}$ & $\begin{array}{r}0.067 \\
(0.72)\end{array}$ & $\begin{array}{l}-0.058 \\
(-0.56)\end{array}$ & $\begin{array}{l}-0.030 \\
(-0.24)\end{array}$ \\
\hline \multicolumn{11}{|c|}{ Panel C: Large size } \\
\hline Mkt- $\mathrm{R}_{\mathrm{f}}$ & $\begin{array}{l}1.067^{* * * *} \\
(40.24)\end{array}$ & $\begin{array}{l}1.057^{* * * *} \\
(40.15)\end{array}$ & $\begin{array}{l}1.052^{* * * *} \\
(36.88)\end{array}$ & $\begin{array}{l}1.092^{* * *} \\
(47.41)\end{array}$ & $\begin{array}{l}1.135^{* * * *} \\
(50.86)\end{array}$ & $\begin{array}{l}0.964^{* * *} \\
(35.67)\end{array}$ & $\begin{array}{l}0.962^{* * *} \\
(36.38)\end{array}$ & $\begin{array}{l}0.907^{* * * *} \\
(37.90)\end{array}$ & $\begin{array}{l}0.948^{* * * *} \\
(41.00)\end{array}$ & $\begin{array}{l}1.011^{* * * *} \\
(45.74)\end{array}$ \\
\hline SMB & $\begin{array}{l}0.160^{* *} \\
(2.07)\end{array}$ & $\begin{array}{l}0.154^{* *} \\
(2.38)\end{array}$ & $\begin{array}{l}0.140^{* *} \\
(2.03)\end{array}$ & $\begin{array}{l}0.222^{* * *} \\
(3.91)\end{array}$ & $\begin{array}{l}0.275^{* * *} \\
(5.91)\end{array}$ & $\begin{array}{l}-0.277^{* * *} \\
(-6.74)\end{array}$ & $\begin{array}{l}-0.154^{* * *} \\
(-4.43)\end{array}$ & $\begin{array}{l}-0.184^{* * *} \\
(-6.33)\end{array}$ & $\begin{array}{l}-0.132^{* * *} \\
(-4.43)\end{array}$ & $\begin{array}{l}-0.070^{*} \\
(-1.68)\end{array}$ \\
\hline HML & $\begin{array}{c}0.015 \\
(0.31)\end{array}$ & $\begin{array}{r}0.097 \\
(1.63)\end{array}$ & $\begin{array}{l}0.125^{* *} \\
(2.08)\end{array}$ & $\begin{array}{c}0.010 \\
(0.21)\end{array}$ & $\begin{array}{l}-0.273^{* * *} \\
(-6.41)\end{array}$ & $\begin{array}{l}-0.052 \\
(-1.34)\end{array}$ & $\begin{array}{c}0.026 \\
(0.36)\end{array}$ & $\begin{array}{l}-0.014 \\
(-0.37)\end{array}$ & $\begin{array}{l}-0.125^{* * *} \\
(-3.45)\end{array}$ & $\begin{array}{l}-0.370^{* * *} \\
(-7.67)\end{array}$ \\
\hline MOM & $\begin{array}{l}-0.127^{* * *} \\
(-3.74)\end{array}$ & $\begin{array}{l}-0.137^{* * *} \\
(-5.24)\end{array}$ & $\begin{array}{l}-0.137^{* * *} \\
(-4.64)\end{array}$ & $\begin{array}{l}-0.182^{* * *} \\
(-6.58)\end{array}$ & $\begin{array}{l}-0.220^{* * * *} \\
(-6.95)\end{array}$ & $\begin{array}{c}0.018 \\
(0.54)\end{array}$ & $\begin{array}{c}0.032 \\
(0.92)\end{array}$ & $\begin{array}{l}-0.003 \\
(-0.11)\end{array}$ & $\begin{array}{l}-0.008 \\
(-0.26)\end{array}$ & $\begin{array}{l}-0.073^{* *} \\
(-2.19)\end{array}$ \\
\hline Constant & $\begin{array}{c}0.181^{*} \\
(1.92)\end{array}$ & $\begin{array}{c}0.165^{*} \\
(1.95)\end{array}$ & $\begin{array}{c}0.124 \\
(1.53)\end{array}$ & $\begin{array}{l}0.190^{* *} \\
(2.37)\end{array}$ & $\begin{array}{l}0.254^{* *} \\
(2.54)\end{array}$ & $\begin{array}{c}0.126 \\
(1.45)\end{array}$ & $\begin{array}{c}0.093 \\
(1.14)\end{array}$ & $\begin{array}{l}-0.012 \\
(-0.16)\end{array}$ & $\begin{array}{l}0.148^{* *} \\
(2.06)\end{array}$ & $\begin{array}{c}0.163^{*} \\
(1.83)\end{array}$ \\
\hline
\end{tabular}

$t$ statistics in parentheses (using Newey-West SEs, 4 lags)
${ }^{*} p<0.10,{ }^{* *} p<0.05,{ }^{* * *} p<0.01$ 
Table 8: Time-series regressions of double-sorted portfolios by size and relative labor intensity (OAPE)

We construct portfolios at the end of June of year $t$ by independently sorting firms by market capitalization and by relative labor intensity (RLI). We use these sorts to calculate July $t$ to June $t+1$ returns. The three size groups are defined using the 20th and 50th NYSE market capitalization percentiles. Relative labor intensity is proxied by operating assets per employee, measured relative to the SIC3 median (Rel. OAPE $=$ OAPE/OAPE ${ }^{\mathrm{SIC} 3}-1$ ). We sort firms into five groups based on the year $t-1$ RLI distribution quintiles excluding small firms. H (L) is the $20 \%$ of observations with the highest (lowest) RLI i.e. the least (most) operating assets per employee in year $t-1$. The explanatory variables are from Kenneth French's webpage: Mkt- $\mathrm{R}_{\mathrm{f}}$ is the market excess return, $\mathrm{SMB}$ is the small minus big return. HML is the high minus low B/M return, MOM is the momentum factor. Stock returns are from the CRSP Merged database. Regressions are estimated on the period July 1976 to December 2009, i.e. 402 monthly observations. We present t-statistics using Newey-West standard errors with 4 lags.

\begin{tabular}{|c|c|c|c|c|c|c|c|c|c|c|}
\hline & \multicolumn{5}{|c|}{ Equally-weighted portfolio returns } & \multicolumn{5}{|c|}{ Value-weighted portfolio returns } \\
\hline & High & RLL4 & RLL3 & RLL2 & Low & High & RLL4 & RLL3 & RLL2 & Low \\
\hline & \multicolumn{10}{|c|}{ Panel A: Small size } \\
\hline Mkt- $\mathrm{R}_{\mathrm{f}}$ & $\begin{array}{l}0.942^{* * *} \\
(23.91)\end{array}$ & $\begin{array}{l}0.945^{* * *} \\
(21.65)\end{array}$ & $\begin{array}{l}1.010^{* * * *} \\
(26.54)\end{array}$ & $\begin{array}{l}1.022^{* * *} \\
(24.29)\end{array}$ & $\begin{array}{l}0.997^{* * *} \\
(21.44)\end{array}$ & $\begin{array}{l}0.985^{* * *} \\
(35.95)\end{array}$ & $\begin{array}{l}1.018^{* * *} \\
(38.80)\end{array}$ & $\begin{array}{l}1.029^{* * *} \\
(38.08)\end{array}$ & $\begin{array}{l}1.041^{* * *} \\
(30.95)\end{array}$ & $\begin{array}{l}1.050^{* * * *} \\
(25.21)\end{array}$ \\
\hline SMB & $\begin{array}{l}1.087^{* * *} \\
(15.64)\end{array}$ & $\begin{array}{l}1.129^{* * *} \\
(15.63)\end{array}$ & $\begin{array}{l}1.104^{* * *} \\
(16.86)\end{array}$ & $\begin{array}{l}1.222^{* * *} \\
(15.59)\end{array}$ & $\begin{array}{l}1.155^{* * *} \\
(11.97)\end{array}$ & $\begin{array}{l}1.253^{* * *} \\
(20.47)\end{array}$ & $\begin{array}{l}1.258^{* * *} \\
(30.97)\end{array}$ & $\begin{array}{l}1.160^{* * *} \\
(29.38)\end{array}$ & $\begin{array}{l}1.192^{* * *} \\
(17.00)\end{array}$ & $\begin{array}{l}1.099^{* * * *} \\
(11.00)\end{array}$ \\
\hline HML & $\begin{array}{l}0.163^{* *} \\
(2.13)\end{array}$ & $\begin{array}{l}0.172^{* *} \\
(2.04)\end{array}$ & $\begin{array}{l}0.199^{* * *} \\
(2.92)\end{array}$ & $\begin{array}{l}0.203^{* *} \\
(2.28)\end{array}$ & $\begin{array}{r}0.147 \\
(1.56)\end{array}$ & $\begin{array}{l}0.129^{* * *} \\
(3.16)\end{array}$ & $\begin{array}{l}0.187^{* * *} \\
(4.04)\end{array}$ & $\begin{array}{l}0.132^{* * *} \\
(2.79)\end{array}$ & $\begin{array}{l}0.186^{* * *} \\
(3.23)\end{array}$ & $\begin{array}{l}0.197^{* * *} \\
(2.84)\end{array}$ \\
\hline MOM & $\begin{array}{l}-0.193^{* * *} \\
(-3.39)\end{array}$ & $\begin{array}{l}-0.228^{* * *} \\
(-3.84)\end{array}$ & $\begin{array}{l}-0.206^{* * *} \\
(-3.75)\end{array}$ & $\begin{array}{l}-0.246^{* * *} \\
(-4.64)\end{array}$ & $\begin{array}{l}-0.251^{* * *} \\
(-3.72)\end{array}$ & $\begin{array}{r}-0.001 \\
(-0.03)\end{array}$ & $\begin{array}{r}-0.036 \\
(-1.14)\end{array}$ & $\begin{array}{c}0.003 \\
(0.09)\end{array}$ & $\begin{array}{l}-0.126^{* * *} \\
(-2.94)\end{array}$ & $\begin{array}{l}-0.085^{*} \\
(-1.80)\end{array}$ \\
\hline Constant & $\begin{array}{l}0.601^{* * *} \\
(3.78)\end{array}$ & $\begin{array}{l}0.583^{* * *} \\
(3.72)\end{array}$ & $\begin{array}{l}0.429^{* * *} \\
(2.89)\end{array}$ & $\begin{array}{l}0.423^{* * *} \\
(2.62)\end{array}$ & $\begin{array}{c}0.224 \\
(1.35)\end{array}$ & $\begin{array}{r}0.137 \\
(1.56)\end{array}$ & $\begin{array}{r}0.167 \\
(1.54)\end{array}$ & $\begin{array}{c}0.050 \\
(0.46)\end{array}$ & $\begin{array}{r}0.106 \\
(0.86)\end{array}$ & $\begin{array}{l}-0.149 \\
(-1.31)\end{array}$ \\
\hline & \multicolumn{10}{|c|}{ Panel B: Medium size } \\
\hline Mkt- $\mathrm{R}_{\mathrm{f}}$ & $\begin{array}{l}1.087^{* * *} \\
(42.98)\end{array}$ & $\begin{array}{l}1.107^{* * *} \\
(41.65)\end{array}$ & $\begin{array}{l}1.109^{* * *} \\
(41.43)\end{array}$ & $\begin{array}{l}1.154^{* * *} \\
(39.98)\end{array}$ & $\begin{array}{l}1.165^{* * *} \\
(38.60)\end{array}$ & $\begin{array}{c}1.062^{* * *} \\
(49.97)\end{array}$ & $\begin{array}{l}1.072^{* * *} \\
(50.97)\end{array}$ & $\begin{array}{l}1.077^{* * *} \\
(41.58)\end{array}$ & $\begin{array}{l}1.112^{* * *} \\
(47.78)\end{array}$ & $\begin{array}{l}1.156^{* * *} \\
(43.16)\end{array}$ \\
\hline SMB & $\begin{array}{l}0.806^{* * *} \\
(9.53)\end{array}$ & $\begin{array}{l}0.845^{* * *} \\
(11.94)\end{array}$ & $\begin{array}{l}0.778^{* * *} \\
(9.53)\end{array}$ & $\begin{array}{l}0.835^{* * *} \\
(9.19)\end{array}$ & $\begin{array}{l}0.904^{* * *} \\
(11.29)\end{array}$ & $\begin{array}{l}0.811^{* * *} \\
(13.77)\end{array}$ & $\begin{array}{c}0.807^{* * *} \\
(15.18)\end{array}$ & $\begin{array}{l}0.777^{* * *} \\
(12.77)\end{array}$ & $\begin{array}{l}0.839^{* * *} \\
(16.11)\end{array}$ & $\begin{array}{l}0.961^{* * *} \\
(22.41)\end{array}$ \\
\hline HML & $\begin{array}{c}0.099^{*} \\
(1.67)\end{array}$ & $\begin{array}{l}0.212^{* * *} \\
(4.06)\end{array}$ & $\begin{array}{l}0.182^{* * *} \\
(3.02)\end{array}$ & $\begin{array}{c}0.112 \\
(1.40)\end{array}$ & $\begin{array}{l}-0.018 \\
(-0.25)\end{array}$ & $\begin{array}{c}0.074 \\
(1.20)\end{array}$ & $\begin{array}{l}0.224^{* * *} \\
(3.77)\end{array}$ & $\begin{array}{l}0.158^{* *} \\
(2.25)\end{array}$ & $\begin{array}{r}0.111 \\
(1.35)\end{array}$ & $\begin{array}{c}0.024 \\
(0.24)\end{array}$ \\
\hline MOM & $\begin{array}{l}-0.157^{* * *} \\
(-4.38)\end{array}$ & $\begin{array}{l}-0.187^{* * *} \\
(-3.59)\end{array}$ & $\begin{array}{l}-0.196^{* * *} \\
(-5.57)\end{array}$ & $\begin{array}{l}-0.179^{* * *} \\
(-4.73)\end{array}$ & $\begin{array}{l}-0.196^{* * *} \\
(-4.31)\end{array}$ & $\begin{array}{l}-0.009 \\
(-0.26)\end{array}$ & $\begin{array}{l}-0.023 \\
(-0.69)\end{array}$ & $\begin{array}{l}-0.050 \\
(-1.17)\end{array}$ & $\begin{array}{l}-0.026 \\
(-0.69)\end{array}$ & $\begin{array}{l}-0.013 \\
(-0.22)\end{array}$ \\
\hline Constant & $\begin{array}{r}0.135 \\
(1.48)\end{array}$ & $\begin{array}{c}0.179^{*} \\
(1.79)\end{array}$ & $\begin{array}{l}0.222^{* *} \\
(2.09)\end{array}$ & $\begin{array}{c}0.098 \\
(0.97)\end{array}$ & $\begin{array}{l}-0.038 \\
(-0.32)\end{array}$ & $\begin{array}{l}-0.033 \\
(-0.37)\end{array}$ & $\begin{array}{c}0.046 \\
(0.53)\end{array}$ & $\begin{array}{c}0.113 \\
(1.10)\end{array}$ & $\begin{array}{l}-0.007 \\
(-0.07)\end{array}$ & $\begin{array}{l}-0.135 \\
(-1.15)\end{array}$ \\
\hline \multicolumn{11}{|c|}{ Panel C: Large size } \\
\hline Mkt-R $\mathrm{R}_{\mathrm{f}}$ & $\begin{array}{l}1.057^{* * *} \\
(36.87)\end{array}$ & $\begin{array}{l}1.085^{* * *} \\
(41.89)\end{array}$ & $\begin{array}{l}1.073^{* * *} \\
(43.57)\end{array}$ & $\begin{array}{l}1.088^{* * *} \\
(57.35)\end{array}$ & $\begin{array}{l}1.102^{\text {**** }} \\
(40.82)\end{array}$ & $\begin{array}{l}1.035^{* * *} \\
(48.83)\end{array}$ & $\begin{array}{l}0.993^{* * *} \\
(36.68)\end{array}$ & $\begin{array}{c}0.929^{* * * *} \\
(43.85)\end{array}$ & $\begin{array}{c}0.929^{* * *} \\
(44.65)\end{array}$ & $\begin{array}{c}0.964^{* * *} \\
(45.14)\end{array}$ \\
\hline SMB & $\begin{array}{l}0.214^{* *} \\
(2.40)\end{array}$ & $\begin{array}{l}0.194^{* * *} \\
(3.56)\end{array}$ & $\begin{array}{l}0.137^{* *} \\
(2.19)\end{array}$ & $\begin{array}{l}0.236^{* * *} \\
(5.09)\end{array}$ & $\begin{array}{l}0.186^{* * * *} \\
(3.17)\end{array}$ & $\begin{array}{l}-0.084 \\
(-1.65)\end{array}$ & $\begin{array}{l}-0.064^{*} \\
(-1.85)\end{array}$ & $\begin{array}{l}-0.164^{* * *} \\
(-5.82)\end{array}$ & $\begin{array}{l}-0.169^{* * *} \\
(-5.76)\end{array}$ & $\begin{array}{l}-0.154^{* * *} \\
(-4.42)\end{array}$ \\
\hline HML & $\begin{array}{r}0.017 \\
(0.33)\end{array}$ & $\begin{array}{r}0.048 \\
(1.10)\end{array}$ & $\begin{array}{l}0.122^{* *} \\
(2.06)\end{array}$ & $\begin{array}{l}-0.002 \\
(-0.05)\end{array}$ & $\begin{array}{l}-0.204^{* * *} \\
(-3.93)\end{array}$ & $\begin{array}{l}-0.017 \\
(-0.47)\end{array}$ & $\begin{array}{r}0.016 \\
(0.44)\end{array}$ & $\begin{array}{l}-0.012 \\
(-0.32)\end{array}$ & $\begin{array}{l}-0.087^{* *} \\
(-2.51)\end{array}$ & $\begin{array}{l}-0.325^{* * *} \\
(-8.95)\end{array}$ \\
\hline MOM & $\begin{array}{l}-0.134^{* * * *} \\
(-4.12)\end{array}$ & $\begin{array}{l}-0.170^{* * * *} \\
(-6.34)\end{array}$ & $\begin{array}{l}-0.137^{* * * *} \\
(-4.25)\end{array}$ & $\begin{array}{l}-0.153^{* * *} \\
(-6.83)\end{array}$ & $\begin{array}{l}-0.216^{* * *} \\
(-6.10)\end{array}$ & $\begin{array}{l}-0.014 \\
(-0.53)\end{array}$ & $\begin{array}{l}-0.042^{*} \\
(-1.87)\end{array}$ & $\begin{array}{l}0.041^{* *} \\
(2.16)\end{array}$ & $\begin{array}{l}0.062^{* * *} \\
(3.20)\end{array}$ & $\begin{array}{l}-0.089^{* *} \\
(-2.50)\end{array}$ \\
\hline Constant & $\begin{array}{r}0.127 \\
(1.34)\end{array}$ & $\begin{array}{l}0.165^{*} \\
(1.87)\end{array}$ & $\begin{array}{l}0.135^{*} \\
(1.65)\end{array}$ & $\begin{array}{l}0.224^{* * *} \\
(3.12)\end{array}$ & $\begin{array}{l}0.238^{* *} \\
(2.51)\end{array}$ & $\begin{array}{l}-0.006 \\
(-0.08)\end{array}$ & $\begin{array}{c}0.061 \\
(0.82)\end{array}$ & $\begin{array}{c}0.041 \\
(0.57)\end{array}$ & $\begin{array}{l}0.108^{*} \\
(1.87)\end{array}$ & $\begin{array}{l}0.161^{*} \\
(1.92)\end{array}$ \\
\hline
\end{tabular}

$t$ statistics in parentheses (using Newey-West SEs, 4 lags)
$* p<0.10,{ }^{* *} p<0.05,{ }^{* * *} p<0.01$ 
Table 9: Adjusted returns of labor intensity sorted portfolios and the effect of industry wage level

We present value-weighted and equally weighted adjusted returns following Daniel et al. (1997) and using Russ Wermers's benchmark data. We use the same sorting methodology based on measures of relative labor intensity (assets per employee and operating assets per employee) as in table 7 . In addition we separate portfolios into high and low wage industries using the US Census LED data. The t-stat of the $\mathrm{H}-\mathrm{L}$ portfolio return is based on Newey-West adjusted SEs (4 lags).

\begin{tabular}{|c|c|c|c|c|c|c|c|c|}
\hline & \multicolumn{4}{|c|}{$\mathrm{APE}$} & \multicolumn{4}{|c|}{ OAPE } \\
\hline & \multicolumn{2}{|c|}{ Low wage } & \multicolumn{2}{|c|}{ High wage } & \multicolumn{2}{|c|}{ Low wage } & \multicolumn{2}{|c|}{ High wage } \\
\hline & VW & EW & VW & EW & VW & EW & VW & EW \\
\hline \multicolumn{9}{|c|}{ Panel A: All firms } \\
\hline $\mathrm{H}$ & 0.136 & 0.294 & 0.009 & 0.357 & 0.104 & 0.275 & -0.006 & 0.375 \\
\hline RLI4 & 0.110 & 0.201 & -0.024 & 0.325 & 0.034 & 0.192 & 0.046 & 0.329 \\
\hline RLI3 & -0.070 & 0.143 & -0.036 & 0.263 & 0.004 & 0.138 & -0.034 & 0.262 \\
\hline RLI2 & 0.056 & 0.098 & 0.024 & 0.167 & 0.136 & 0.136 & -0.031 & 0.221 \\
\hline $\mathrm{L}$ & -0.040 & -0.013 & 0.072 & 0.152 & -0.091 & -0.025 & 0.018 & 0.079 \\
\hline $\mathrm{H}-\mathrm{L}$ & 0.175 & 0.307 & -0.063 & 0.206 & 0.195 & 0.300 & -0.024 & 0.296 \\
\hline$t$-stat & 1.444 & 3.321 & -0.462 & 1.880 & 1.663 & 3.230 & -0.198 & 3.646 \\
\hline \multicolumn{9}{|c|}{ Panel B: Small size } \\
\hline $\mathrm{H}$ & 0.161 & 0.388 & 0.208 & 0.475 & 0.143 & 0.365 & 0.251 & 0.522 \\
\hline RLI4 & 0.021 & 0.336 & 0.312 & 0.548 & 0.085 & 0.294 & 0.308 & 0.482 \\
\hline RLI3 & 0.102 & 0.260 & 0.218 & 0.337 & 0.053 & 0.274 & 0.066 & 0.314 \\
\hline RLI2 & 0.086 & 0.121 & 0.122 & 0.315 & -0.123 & 0.121 & 0.275 & 0.501 \\
\hline $\mathrm{L}$ & -0.267 & 0.015 & -0.025 & 0.265 & -0.147 & 0.035 & -0.077 & 0.134 \\
\hline $\mathrm{H}-\mathrm{L}$ & 0.428 & 0.373 & 0.233 & 0.210 & 0.290 & 0.330 & 0.329 & 0.388 \\
\hline$t$-stat & 2.872 & 2.732 & 1.536 & 1.571 & 2.063 & 2.391 & 2.020 & 3.170 \\
\hline \multicolumn{9}{|c|}{ Panel C: Medium size } \\
\hline $\mathrm{H}$ & 0.034 & 0.141 & 0.042 & 0.159 & 0.017 & 0.138 & 0.030 & 0.123 \\
\hline RLI4 & -0.022 & 0.070 & 0.116 & 0.093 & 0.064 & 0.123 & 0.123 & 0.173 \\
\hline RLI3 & 0.157 & 0.200 & 0.116 & 0.170 & 0.135 & 0.159 & 0.143 & 0.180 \\
\hline RLI2 & 0.056 & 0.083 & -0.081 & -0.000 & 0.106 & 0.143 & -0.036 & -0.018 \\
\hline $\mathrm{L}$ & 0.070 & -0.010 & 0.040 & 0.027 & -0.022 & -0.099 & 0.008 & -0.009 \\
\hline $\mathrm{H}-\mathrm{L}$ & -0.036 & 0.151 & 0.002 & 0.132 & 0.039 & 0.237 & 0.022 & 0.132 \\
\hline$t$-stat & -0.252 & 1.102 & 0.013 & 0.818 & 0.275 & 1.745 & 0.135 & 0.855 \\
\hline \multicolumn{9}{|c|}{ Panel D: Large size } \\
\hline $\mathrm{H}$ & 0.150 & 0.110 & 0.003 & 0.091 & 0.122 & 0.065 & -0.024 & 0.034 \\
\hline RLI4 & 0.118 & 0.027 & -0.038 & 0.096 & 0.022 & 0.024 & 0.033 & 0.151 \\
\hline RLI3 & -0.096 & -0.072 & -0.044 & 0.189 & -0.008 & -0.049 & -0.049 & 0.205 \\
\hline RLI2 & 0.060 & 0.092 & 0.030 & 0.101 & 0.148 & 0.184 & -0.028 & 0.079 \\
\hline $\mathrm{L}$ & -0.030 & -0.016 & 0.083 & 0.135 & -0.089 & -0.063 & 0.023 & 0.113 \\
\hline $\mathrm{H}-\mathrm{L}$ & 0.180 & 0.126 & -0.080 & -0.044 & 0.210 & 0.128 & -0.046 & -0.079 \\
\hline$t$-stat & 1.299 & 0.957 & -0.546 & -0.351 & 1.543 & 1.059 & -0.334 & -0.802 \\
\hline
\end{tabular}


Table 10: Returns of labor intensity sorted portfolios and the effect of financial leverage

We present value-weighted excess and adjusted returns (adjustment following Daniel et al. (1997), using Russ Wermers's data). We use the same sorting methodology based on a measure of relative labor intensity (assets per employee) and size as in table 7. In addition we independently sort stocks into high, medium and low financial leverage using the 30th and 70th percentiles. We define financial leverage as long-term debt and debt in current liabilities divided by total assets. The t-stat of the $\mathrm{H}-\mathrm{L}$ portfolio return is based on Newey-West adjusted SEs (4 lags).

\begin{tabular}{|c|c|c|c|c|c|c|}
\hline & \multicolumn{3}{|c|}{ Excess returns, VW } & \multicolumn{3}{|c|}{ DGTW adj. returns, VW } \\
\hline & Hi Lev & Mid Lev & Lo Lev & Hi Lev & Mid Lev & Lo Lev \\
\hline \multicolumn{7}{|c|}{ Panel A: Small size } \\
\hline $\mathrm{H}$ & 0.933 & 1.100 & 0.977 & 0.096 & 0.263 & 0.181 \\
\hline RLI4 & 0.962 & 1.124 & 1.060 & 0.096 & 0.243 & 0.258 \\
\hline RLI3 & 0.979 & 1.082 & 0.986 & 0.063 & 0.173 & 0.197 \\
\hline RLI2 & 0.949 & 0.907 & 0.836 & 0.150 & 0.012 & 0.080 \\
\hline $\mathrm{L}$ & 0.497 & 0.633 & 0.799 & -0.344 & -0.172 & 0.069 \\
\hline $\mathrm{H}-\mathrm{L}$ & 0.436 & 0.467 & 0.178 & 0.440 & 0.436 & 0.113 \\
\hline$t$-stat & 2.486 & 2.859 & 1.033 & 2.514 & 2.733 & 0.655 \\
\hline \multicolumn{7}{|c|}{ Panel B: Medium size } \\
\hline $\mathrm{H}$ & 0.814 & 0.763 & 0.770 & 0.084 & 0.004 & 0.017 \\
\hline RLI4 & 0.873 & 0.940 & 0.693 & 0.013 & 0.139 & -0.045 \\
\hline RLI3 & 0.880 & 0.864 & 0.795 & 0.118 & 0.099 & 0.141 \\
\hline RLI2 & 0.946 & 0.878 & 0.404 & 0.139 & 0.096 & -0.240 \\
\hline $\mathrm{L}$ & 0.894 & 0.709 & 0.673 & 0.106 & -0.043 & 0.046 \\
\hline $\mathrm{H}-\mathrm{L}$ & -0.080 & 0.054 & 0.097 & -0.022 & 0.046 & -0.028 \\
\hline$t$-stat & -0.373 & 0.271 & 0.465 & -0.107 & 0.259 & -0.147 \\
\hline \multicolumn{7}{|c|}{ Panel C: Large size } \\
\hline $\mathrm{H}$ & 0.520 & 0.602 & 0.416 & -0.063 & 0.075 & -0.041 \\
\hline RLI4 & 0.729 & 0.605 & 0.582 & 0.141 & 0.014 & 0.080 \\
\hline RLI3 & 0.276 & 0.484 & 0.505 & -0.149 & -0.078 & 0.073 \\
\hline RLI2 & 0.554 & 0.592 & 0.478 & -0.046 & 0.093 & -0.020 \\
\hline $\mathrm{L}$ & 0.330 & 0.422 & 0.739 & -0.095 & -0.054 & 0.187 \\
\hline $\mathrm{H}-\mathrm{L}$ & 0.189 & 0.180 & -0.323 & 0.032 & 0.129 & -0.228 \\
\hline$t$-stat & 1.107 & 0.960 & -1.492 & 0.215 & 0.848 & -1.450 \\
\hline
\end{tabular}


Figure 1: Moving-window abnormal returns of double-sorted portfolios by size and relative labor intensity.

We regress value-weighted monthly excess returns of double-sorted portfolios on four Fama-FrenchCarhart factors (Kenneth French data). The sorting procedure is described in table 7. For each size group we present the top, middle and bottom quintiles of relative labor intensity (proxied by relative assets per employee). The t-stats are based on Newey-West SEs (4 lags). Shaded areas are NBER recession months.

Alpha

Panel A: Small firms

t-stat of Alpha
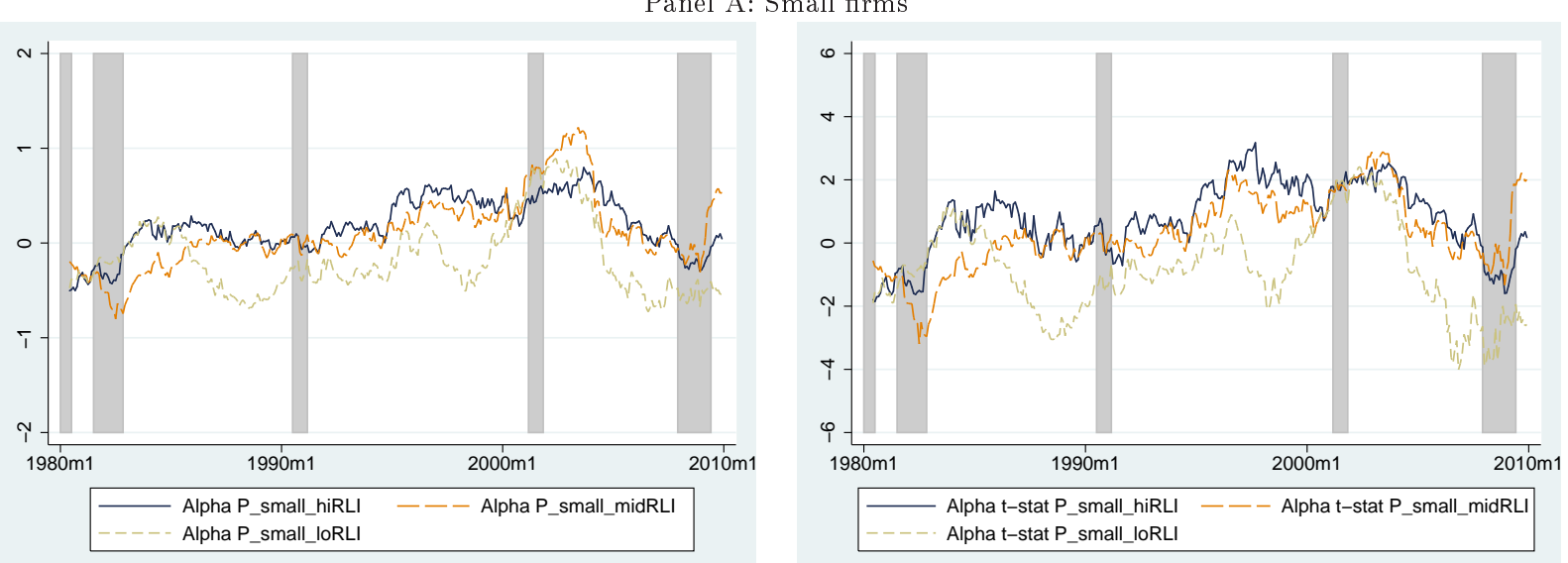

Panel B: Medium-sized firms
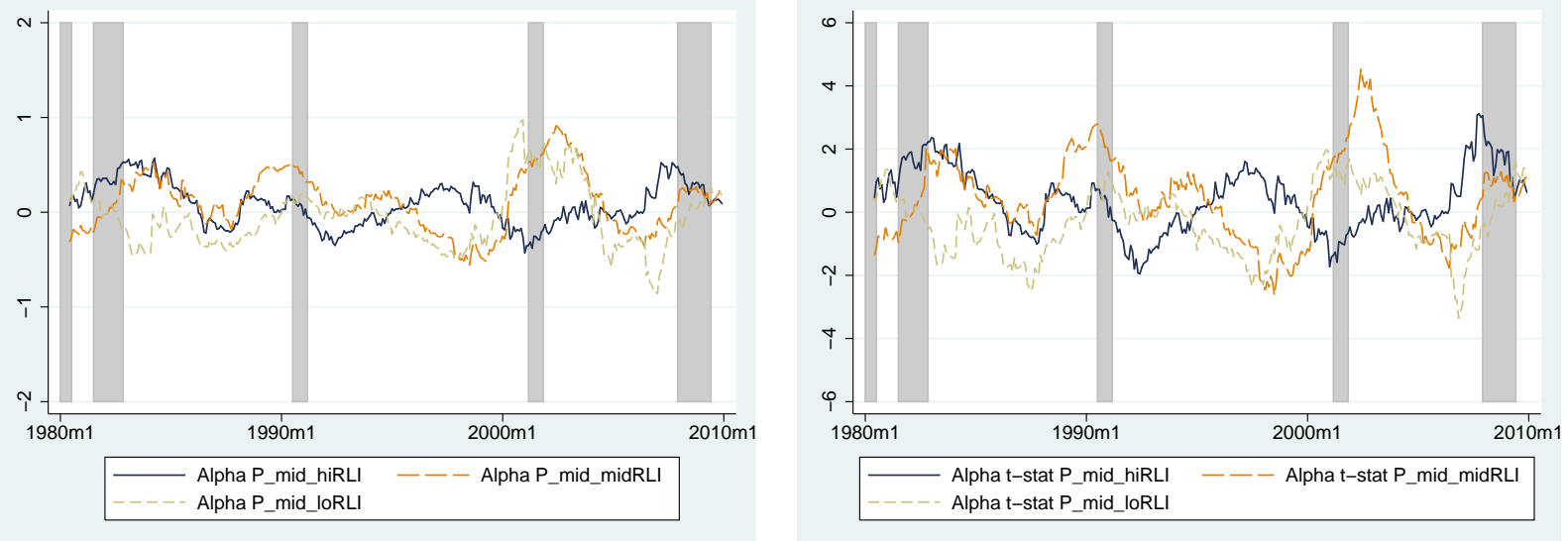

Panel C: Big firms
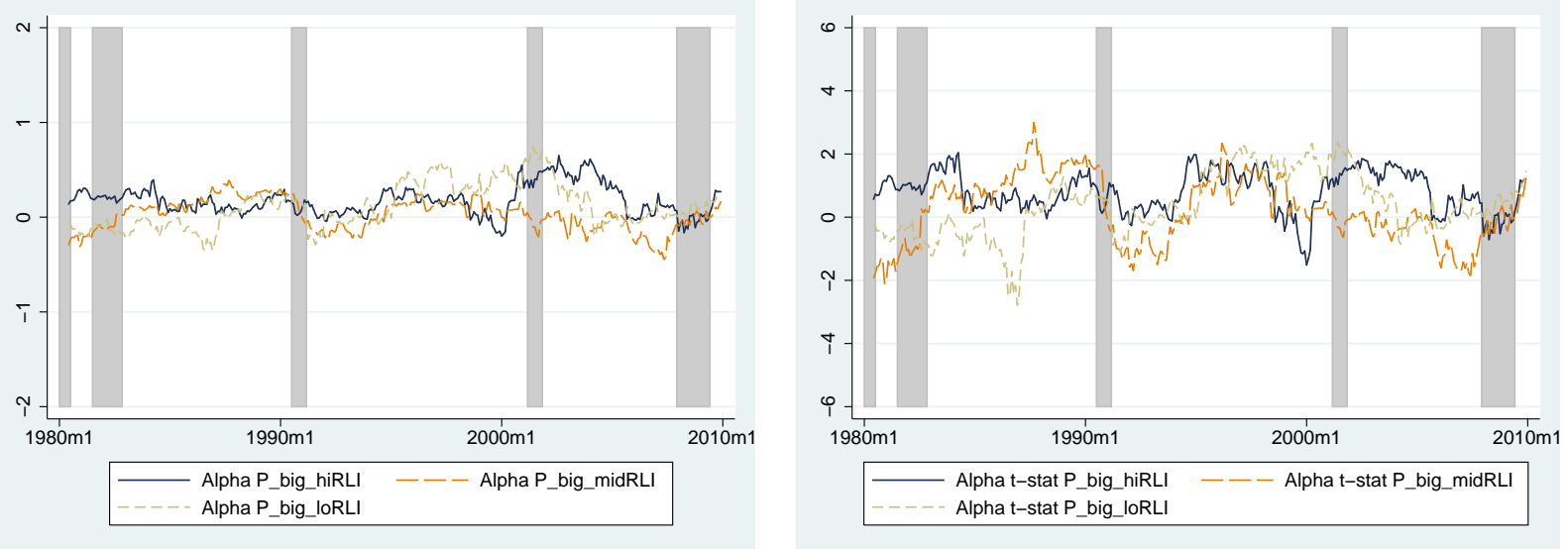